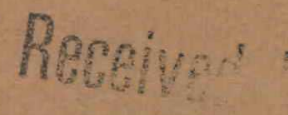

$0 S 7 /$ DOE/RL $89-21$

SEP $8 \quad 1989$

\title{
Application for Approval for Construction of the Fueled Clad Fabrication System, the Radioisotope Power Systems Facility, and the Fuel Assembly Area
}

\section{DO NOT MICROFLLM \\ COVER}

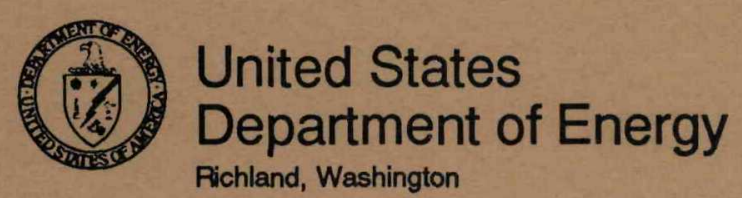




\section{DISCLAIMER}

This report was prepared as an account of work sponsored by an agency of the United States Government. Neither the United States Government nor any agency Thereof, nor any of their employees, makes any warranty, express or implied, or assumes any legal liability or responsibility for the accuracy, completeness, or usefulness of any information, apparatus, product, or process disclosed, or represents that its use would not infringe privately owned rights. Reference herein to any specific commercial product, process, or service by trade name, trademark, manufacturer, or otherwise does not necessarily constitute or imply its endorsement, recommendation, or favoring by the United States Government or any agency thereof. The views and opinions of authors expressed herein do not necessarily state or reflect those of the United States Government or any agency thereof. 


\section{DISCLAIMER}

Portions of this document may be illegible in electronic image products. Images are produced from the best available original document. 


\section{Application for Approval for Construction of the Fueled Clad Fabrication System, the Radioisotope Power Systems Facility, and the Fuel Assembly Area}

Date Published

August 1989

United States

Department of Energy 


\section{CONTENTS}

Application for Approval of Construction of the Fueled Clad Fabrication Facility, the Radioisotope Power

Systems Facility, and the Fuel Assembly Area

\section{Application for Approval of Construction Fueled Clad Fabrication System}

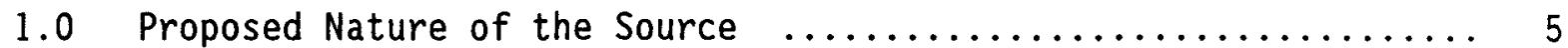

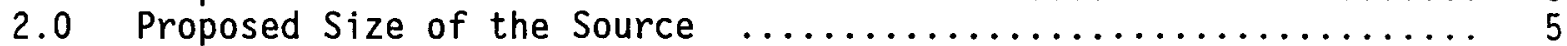

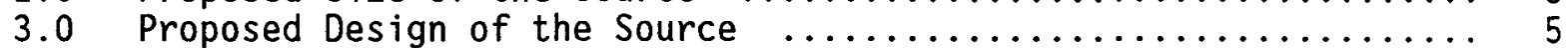

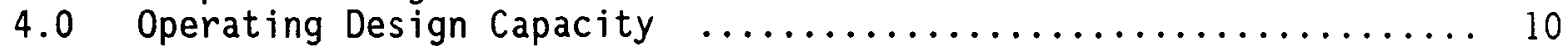

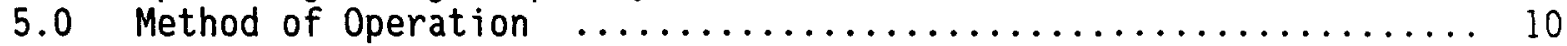

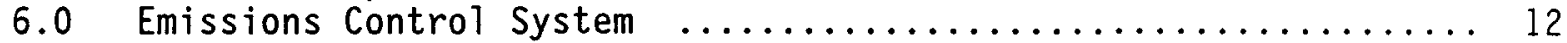

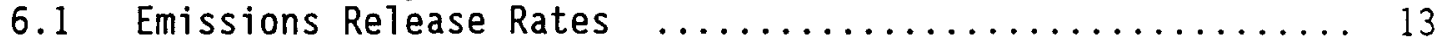

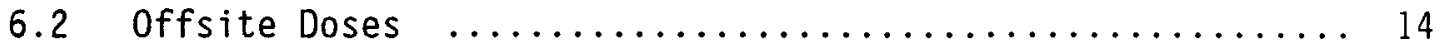

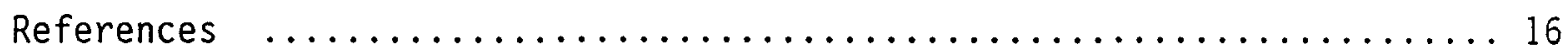

Application for Approval of Construction Radioisotope Power Systems Facility

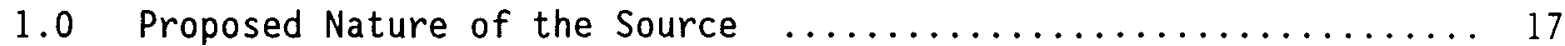

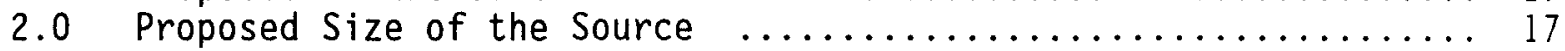

3.0 Proposed Design of the Source $\ldots \ldots \ldots \ldots \ldots \ldots \ldots \ldots \ldots \ldots \ldots \ldots$

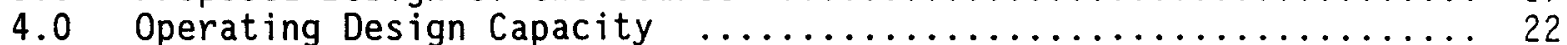

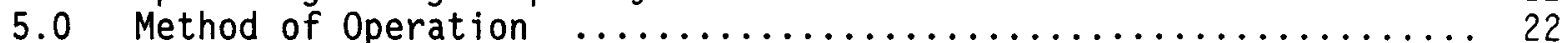

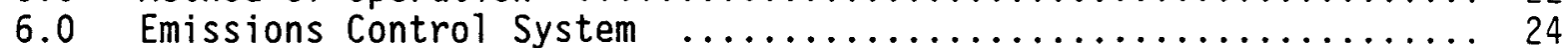

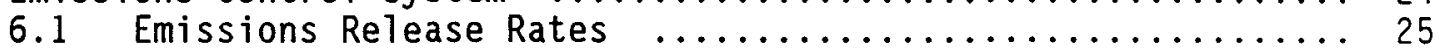

6.2 Offsite Doses ............................ 26

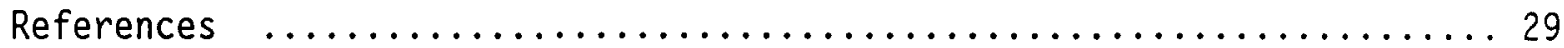

\section{Application for Approval of Construction Fuel Assembly Area}

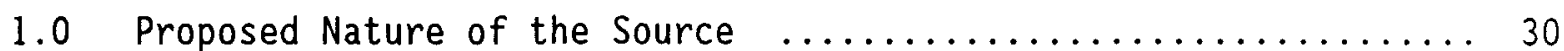

2.0 Proposed Size of the Source ....................... 30

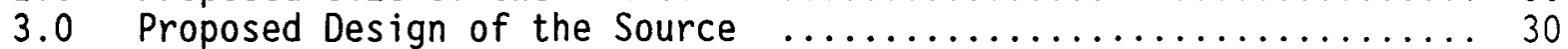

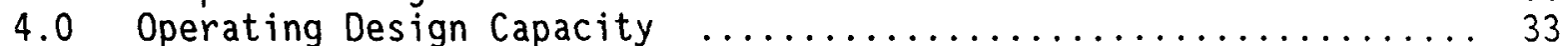

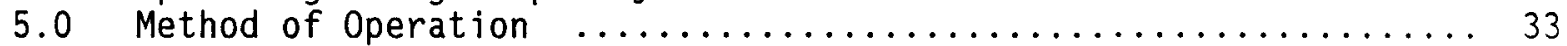

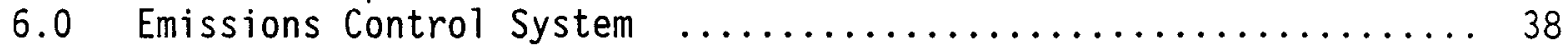

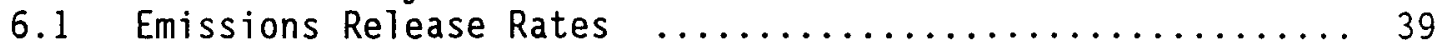

6.2 Offsite Doses .......................... 40

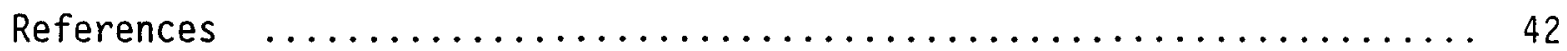




\section{LIST OF FIGURES}

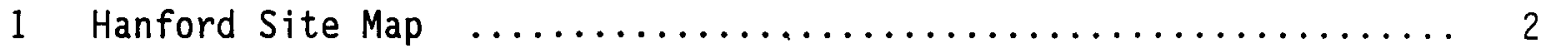

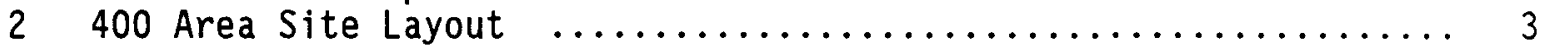

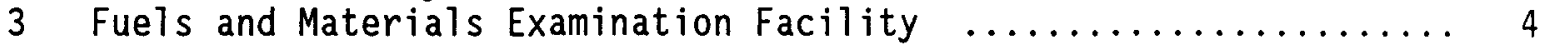

4 General Purpose Heat Source Module Assembly ................ 6

5 FMEF Hot Ce11s Located; 10.7 Meters (35 Feet)

Belowgrade in the Process Building $\ldots \ldots \ldots \ldots \ldots \ldots \ldots \ldots, 7$

6 Fueled Fabrication System Cell Atmosphere Systems ............ 8

7 Overall Process Flow Diagram for the Fueled Fabrication

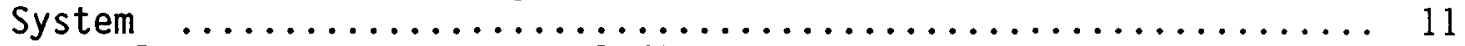

8 General Purpose Heat Source Radioisotope Thermoelectric Generator .......................... 18

9 Radioisotope Power System Facility Floor Plan -5.2-Meters

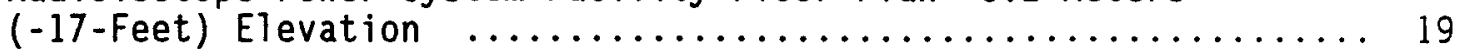

10 Radioisotope Power System Facility Floor Plan -10.7-Meters

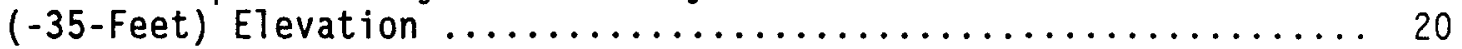

11 Radioisotope Power System Facility Cell Atmosphere

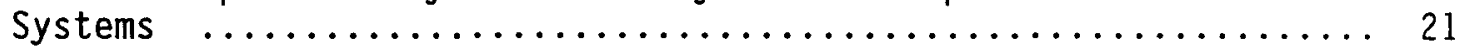

12 Overall Process Flow Diagram for Radioisotope Power

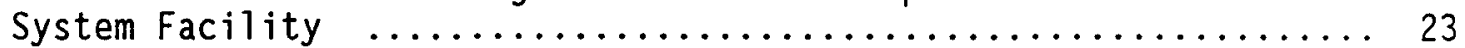

13 Fuel Assembly Area Floor Plan .............................. 31

14 Fuel Assembly Area Zone I Exhaust Flow Diagram ............... 32

15 Overall Process Flow Diagram for Enriched Uranium Oxide

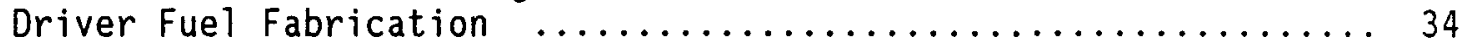

16 Overall Process Flow Diagram for Neptunium Target Pin Fabrication in the Fuel Assembly Area $\ldots \ldots \ldots \ldots \ldots \ldots \ldots . . \ldots . . .65$ 


\section{LIST OF TABLES}

1-1 Controlled Particle Radionuclide Emission

Rates for Fueled $\mathrm{Cl}$ ad Fabrication System

1-2 Offsite Dose Estimates for an Individual Receiving Maximum Exposure to Airborne Radiological Emissions from Fueled Clad Fabrication System ......................... 15

2-1 Controlled Particle Radionuclide Emission Rates for Radioisotope Power System Facility

2-2 Offsite Dose Estimates for an Individual Receiving Maximum Exposure to Airborne Radiological Emissions from Radioisotope Power System Facility

3-1 Controlled Particle Radionuclide Emission Rates Projected for Fuel Assembly Area ................................ 39

3-2 Offsite Dose Estimates for an Individual Receiving Maximum Exposure to Airborne Radiological Emissions from

Fuel Assembly Area 


\section{APPLICATION FOR APPROVAL OF CONSTRUCTION OF THE FUELED CLAD FABRICATION FACILITY, THE RADIOISOTOPE POWER SYSTEMS FACILITY, AND THE FUEL ASSEMBLY AREA}

The following "Application for Approval of Construction" is being submitted by the U.S. Department of Energy-Richland Operations Office (P.0. Box 550, Richland, Washington, 99352), pursuant to 40 CFR 61.07, for three new sources of airborne radionuclide emissions at the Hanford Site in Washington State (Figure 1). The three new sources, the Fueled Clad Fabrication System (FCFS), the Radioisotope Power Systems Facility (RPSF), and the Fuel Assembly Area (FAA), will be located in one facility, the Fuels and Materials Examination Facility (FMEF) of the 400 Area as shown in Figures 2 and 3 .

The FMEF was originally designed to provide for post-irradiation examination and fabrication of breeder reactor fuels. These FMEF missions were cancelled before the introduction of any fuel materials or any irradiated material. The current plans are to use the facility to fabricate power supplies to be used in space applications and to produce Fast Flux Test Facility (FFTF) fuel and target assemblies. The FCFS and the RPSF will produce materials and assemblies for application in space. The FAA project will produce FFTF fuel and target assemblies.

The FCFS and the RPSF will share the same building and stack and, in certain cases, the same floor space. Given this relationship, these systems will be dealt with separately to the extent possible. The FAA is a comparatively independent operation though it will share the FMEF complex, as shown in Figure 3. 


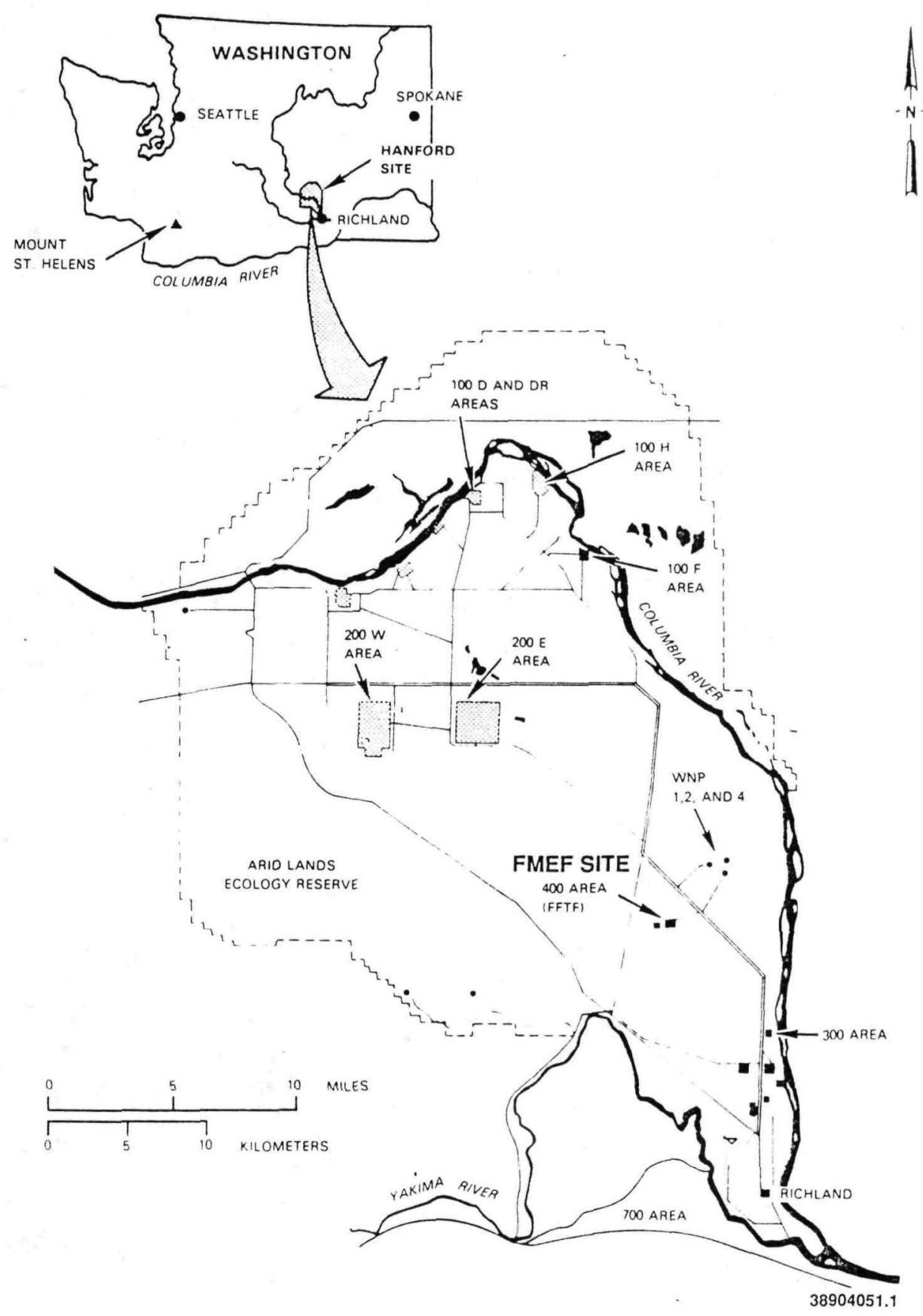

Figure 1. Hanford Site Map. 


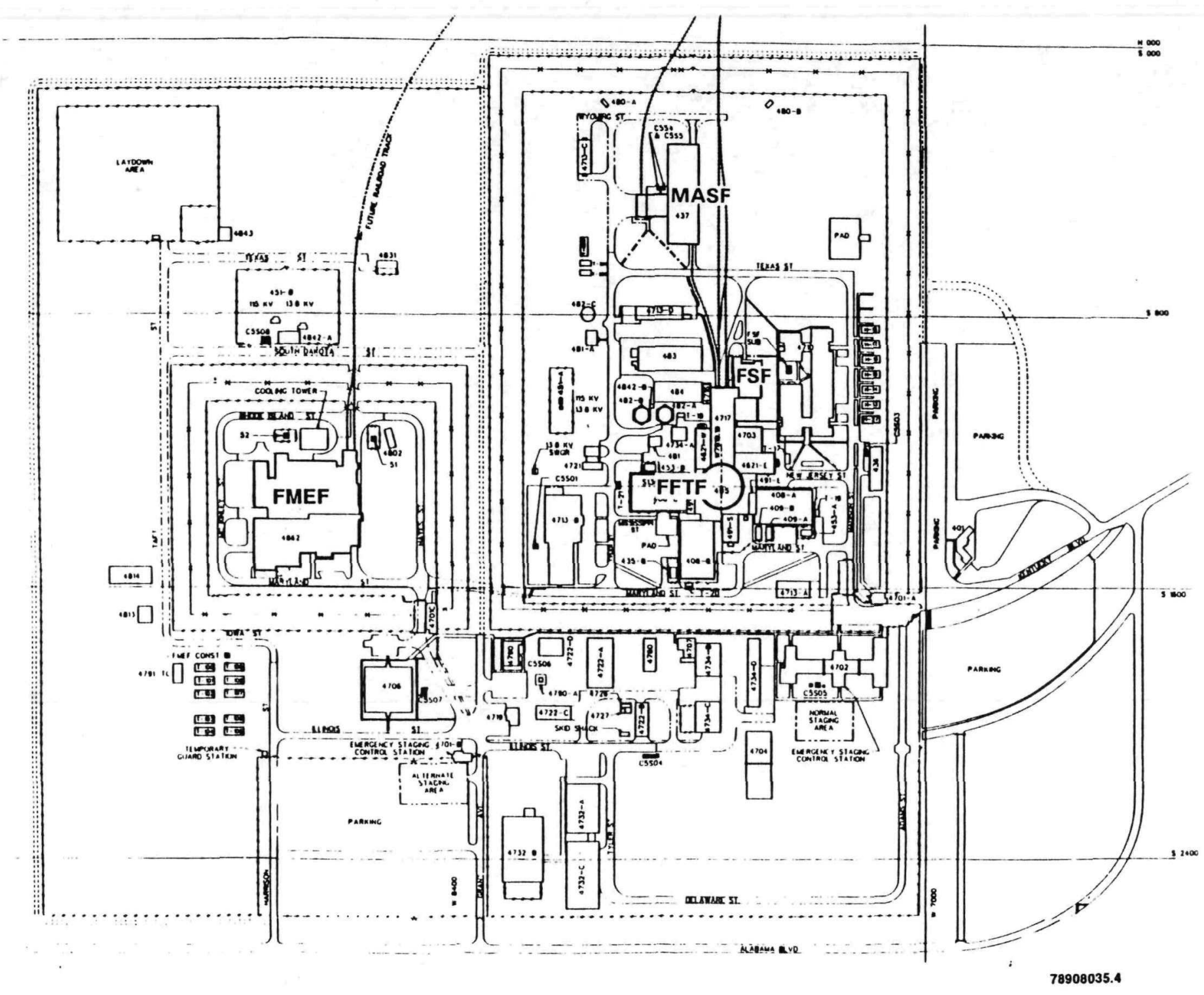

Figure 2. 400 Area Site Layout. 


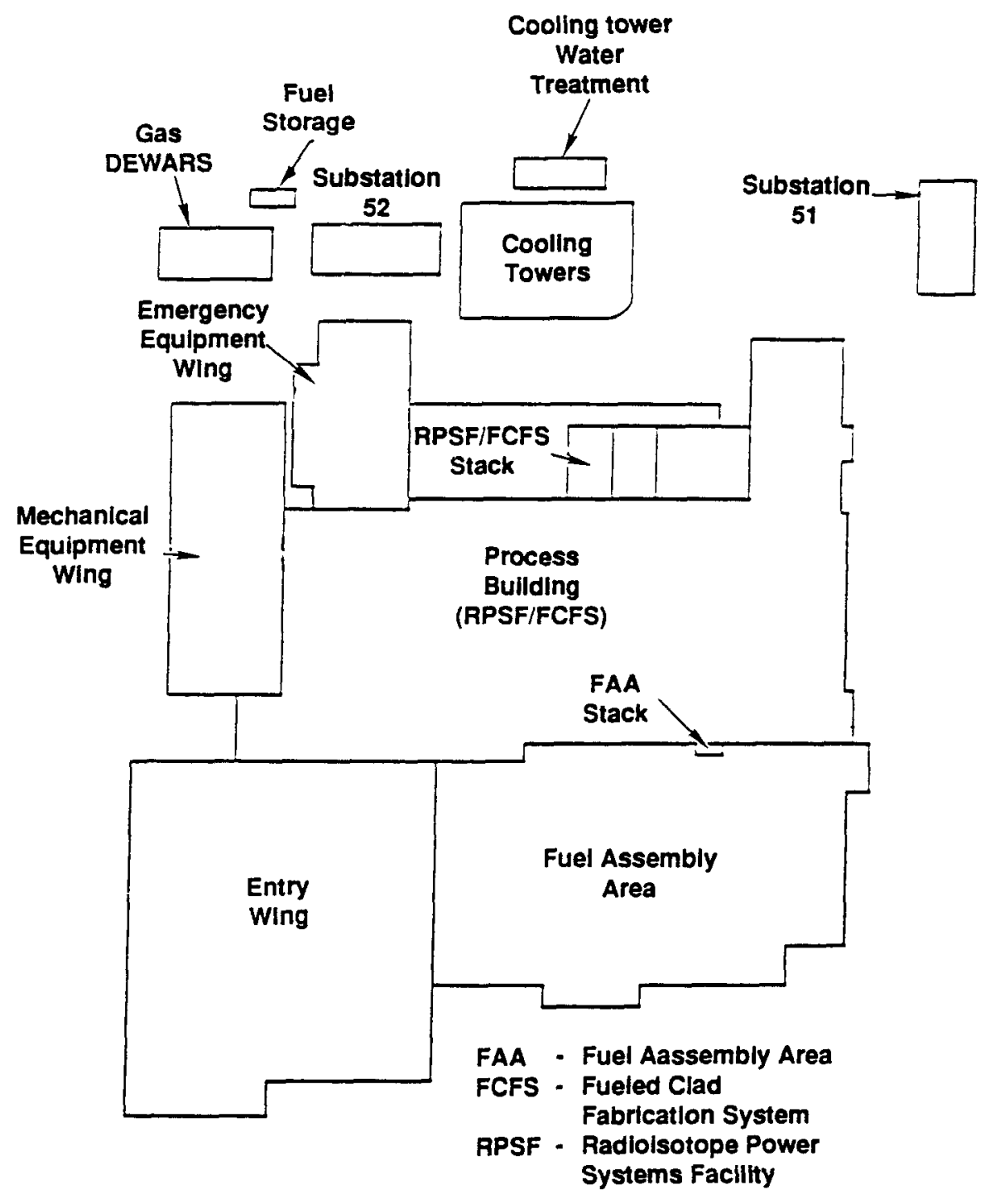

Figure 3. Fuels and Materials Examination Facility. 


\section{APPLICATION FOR APPROVAL OF CONSTRUCTION FUELED CLAD FABRICATION SYSTEM}

\subsection{PROPOSED NATURE OF THE SOURCE}

The Fueled Clad Fabrication System (FCFS) will process special nuclear materials. The FCFS will fabricate $238 \mathrm{PuO}_{2}$ pellets from powder and encapsulate them in fueled clads (FC) for use as heat sources in general purpose heat source (GPHS) modules. Figure 4 shows an FC in a GPHS module.

\subsection{PROPOSED SIZE OF THE SOURCE}

The FCFS will be located in the Fuel and Materials Examination Facility (FMEF) Process Building on the $-10.7-\mathrm{m}(-35-\mathrm{ft})$ level. Figure 5 shows those sections of the FMEF to be used by the FCFS.

The Process Building is a six-level, tornado-hardened, seismically qual ified concrete structure $79.2 \mathrm{~m}(260 \mathrm{ft})$ long and $47.2 \mathrm{~m}(155 \mathrm{ft})$ wide, extending from $10.7 \mathrm{~m}(35 \mathrm{ft})$ belowgrade to approximately $30.4 \mathrm{~m}(100 \mathrm{ft})$ abovegrade. Most of the facilities capabilities for handling radioactive materials are centered in the Process Building.

\subsection{PROPOSED DESIGN OF THE SOURCE}

The FCFS will be provided with ventilation Zones I, II, and III and with airlocks as required for zone separation in high-traffic access areas. Areas denoted Zone I will contain the radioactive materials being processed and will be separated from surrounding ventilation Zone II areas.

Ventilation Zone III areas will be those support areas that bound ventilation Zone II. There will be a negative pressure gradient from Zone III to I so that any contaminants will flow into Zone I and through the facility emissions abatement systems. All Zone I air flows out the FMEF stack.

Releases of radioactive materials to the ventilation system will occur in Zone I and may occur in Zone II. Releases of radioactive materials to the ventilation system from Zone III are unlikely. The process activities described in Section 5.0 will take place in these zones. The cells to be used for $238 \mathrm{PuO}_{2}$ pellet encapsulation are shown in Figure 5 . Figure 6 depicts FCFS cell atmosphere flow and indicates points of emission to the environment. 


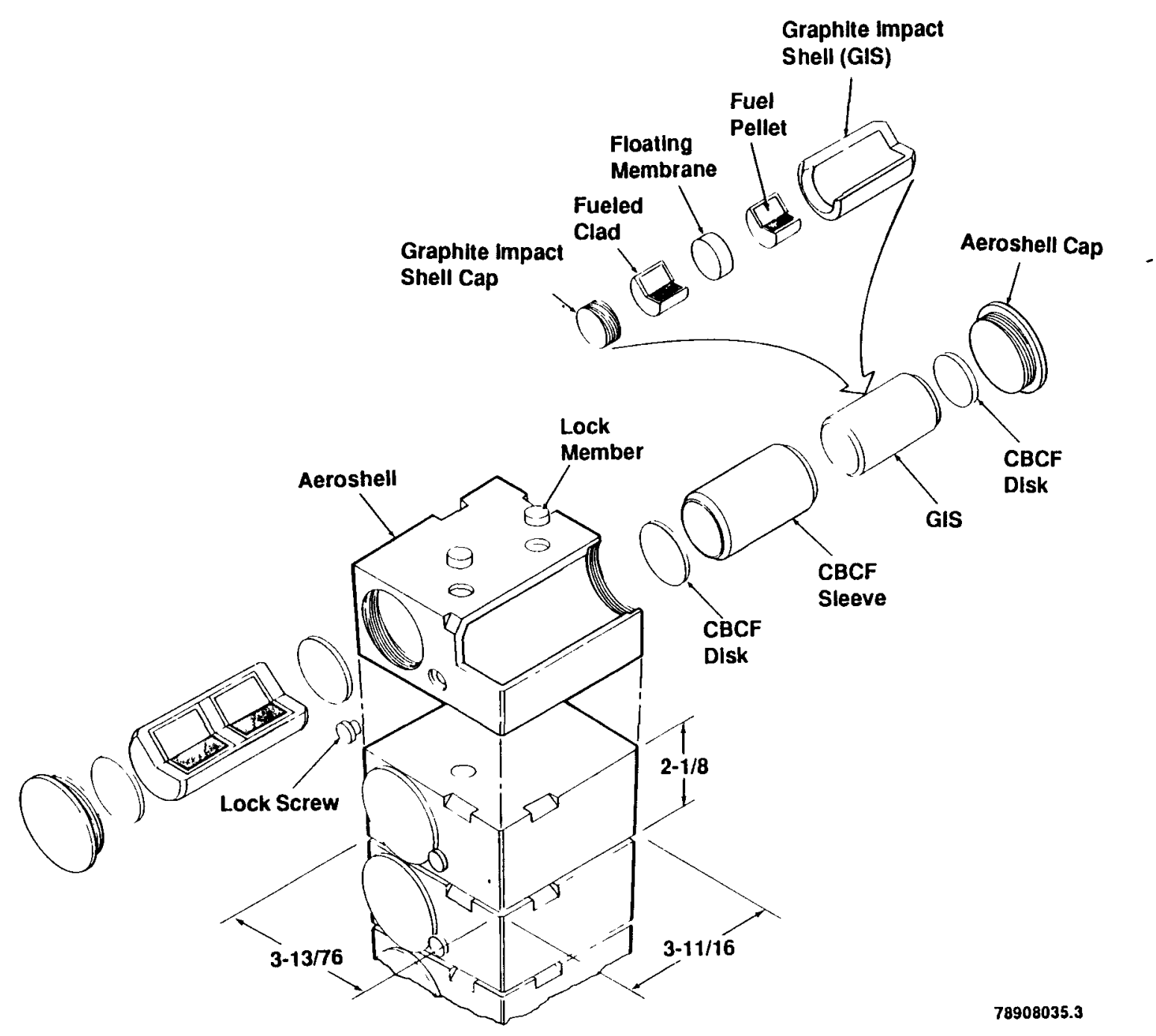

Figure 4. General Purpose Heat Source Module Assembly. 


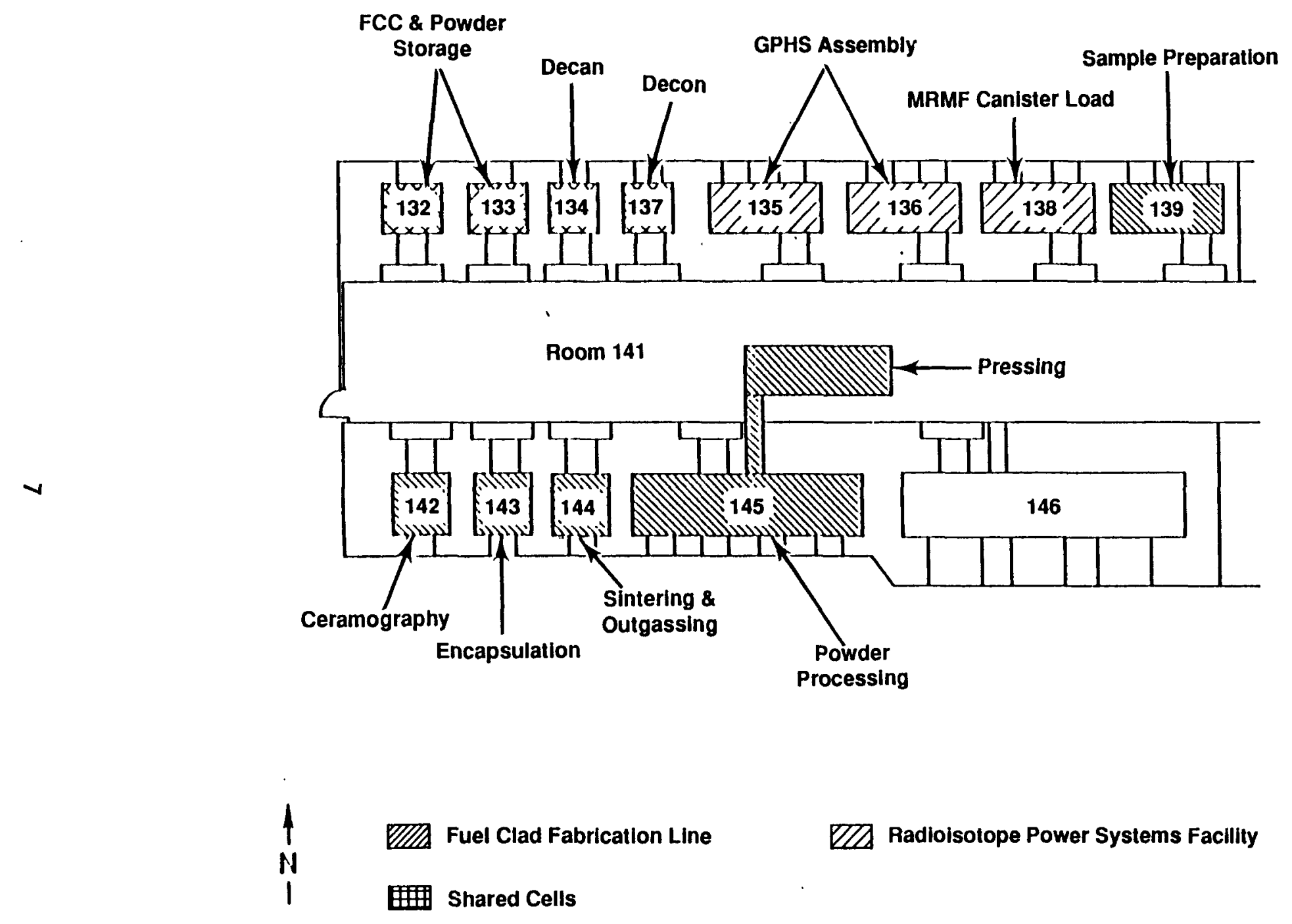

Figure 5. FMEF Hot Cells Located 10.7 Meters (35 Feet) Belowgrade in the Process Building. 


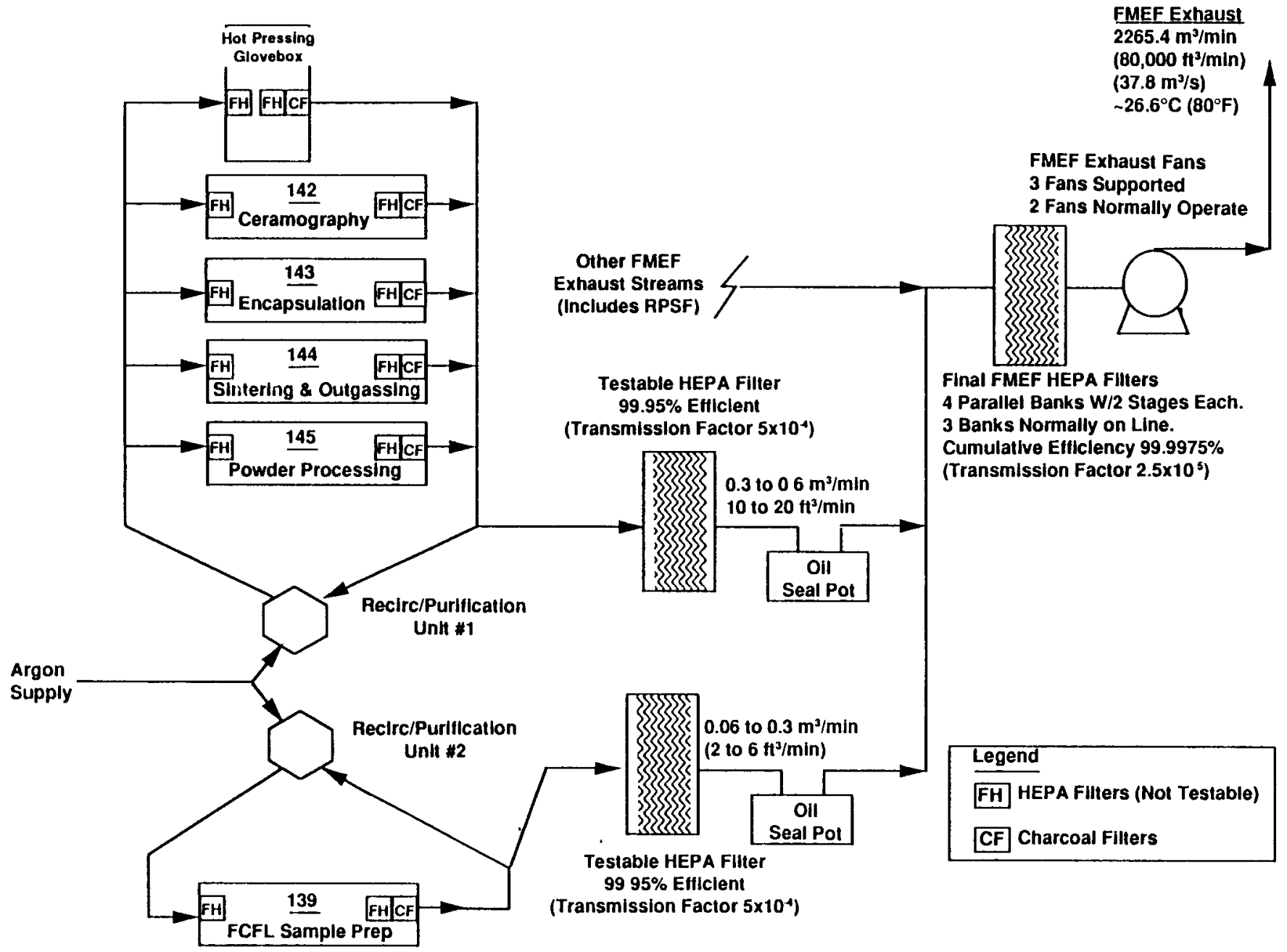

Figure 6. Fueled $\mathrm{Cl}$ ad Facility System Cell Atmosphere Systems. 


\section{Zone I}

Cells 132, 133, 137, 139, 142, 143, 144, 145, and the glovebox in room 141 will be part of the Zone I ventilation system. With the exception of cells 132 and 133, these cells will be used in the processing of the plutonium dioxide powder into pellets and in the encapsulation of these pellets. Cells 132 and 133 will be used to store the plutonium dioxide powder. Because the plutonium dioxide powder will be contained in a canister, the potential for releases of radioactive materials to the ventilation system is small. The relative contributions of the processing steps to the radioactive releases are discussed below.

Cell 145 will be used for powder processing. Powder processing includes opening the canisters containing the powder, sampling the powder, transferring powder into furnace boats, performing the ${ }^{16} 0_{2}$ exchange, ball milling the powder, sieving the powder, cold pressing the powder, sintering the granules, sieving the shards, and ball milling the shards. These operations will produce the majority of the particulate radioactive materials that reach the ventilation system. Gaseous emissions from the ${ }^{16} 0_{2}$ furnace and the sintering furnace are not expected because plutonium dioxide is not volatile.

The glovebox in room 141 will be used for hot pressing the shards into pellets. Cell 144 will be used for sintering and vacuum heat-treating the pellets. Powder will not be handled in cell 144 enclosures nor will there be any operations performed (such as grinding) that may result in the production of particulate matter. However, because the plutionium dioxide is not yet encapsulated, the release of particulate radioactive materials to the ventilation system is expected to be relatively moderate in relation to other operations. Gaseous emissions from hot pressing and from the sintering and vacuum heat-treating furnaces are not expected, because plutonium dioxide is not volatile.

Cell 139 will be used to prepare sample pellets for ceramography in cell 142. Sample preparation will include grinding, polishing, mounting, and etching. Grinding and polishing operations have the potential for the production of particulate matter; therefore, releases of particulate matter from cell 139 are expected. The potential for releases of radioactive materials during sample characterization by ceramography in cell 142 will be smal1.

In cell 143, pellets will be loaded into iridium cladding and the cladding will be welded shut. In cell 137, the FCs will be decontaminated. During pellet loading and decontamination, surface particulate contamination may become suspended. Releases are not expected to be nearly as great as during powder handling operations; therefore, the release of particulate radioactive materials to the ventilation system from these cells is expected to be small. 
Following decontamination, nondestructive examination of $F C s$ will also be performed in cell 137. Because the plutonium dioxide pellets will be encapsulated in a cladding that has been decontaminated, the potential for releases of radioactive materials is small.

\section{Zone II}

Rooms 126, 127, 174, 149, 153, 148, 141, 152, and operating corridors 131,123 , and $125 \mathrm{~W}$ will be part of the Zone II ventilation system. Releases of radioactive materials to the Zone II ventilation system are not likely to occur because processing of radioactive materials will not occur in the Zone II rooms; the negative pressure gradient from Zone II to Zone I would carry any release to the Zone I ventilation system; and there are backdraft dampers acting as check-valves between Zone II and Zone III.

\section{Zone III}

Zone III includes those areas surrounding the Zone II ventilation area. Releases of radioactive materials to the Zone III ventilation system are highly unlikely because of the negative pressure gradient between Zone III and Zone II, and because radioactive materials will not be handled in the Zone III room.

\subsection{OPERATING DESIGN CAPACITY}

The FCFS is intended to operate $8 \mathrm{~h} / \mathrm{d}, 5 \mathrm{~d} / \mathrm{wk}, 52 \mathrm{wk} / \mathrm{yr}$ including maintenance downtime.

Production rates are stated in terms of FCs. The normal production rate is $200 \mathrm{FC} / \mathrm{yr}$.

\subsection{METHOD OF OPERATION}

An overall process flow diagram is shown in Figure 7 .

Plutonium dioxide powder will be received in rooms 524 and 526, located $12.8 \mathrm{~m}(42 \mathrm{ft}$ ) abovegrade in the FMEF. A nondestructive assay will be performed on the containers of plutonium dioxide. The containers will then be stored in cells 132 or 133 .

Canisters of powder will be transferred from storage to cell 145 for processing. The canisters will be cut open and sampled for chemical characterization. The bulk of the powder will be loaded into furnace boats and placed in a furnace. In the furnace, ${ }^{16} \mathrm{O}_{2}$ will replace ${ }^{17} \mathrm{O}_{2}$ and ${ }^{18} \mathrm{O}_{2}$ in the $238 \mathrm{PuO}_{2}$ powder. This results in a significant reduction of the neutron emission rate, which is necessary for the use of the $238 \mathrm{PuO}_{2}$ in power sources. After oxygen exchange, the $238 \mathrm{PuO}_{2}$ powder will be ball milled, sieved, cold pressed, and granulated. The granules will be sintered into shards in an 

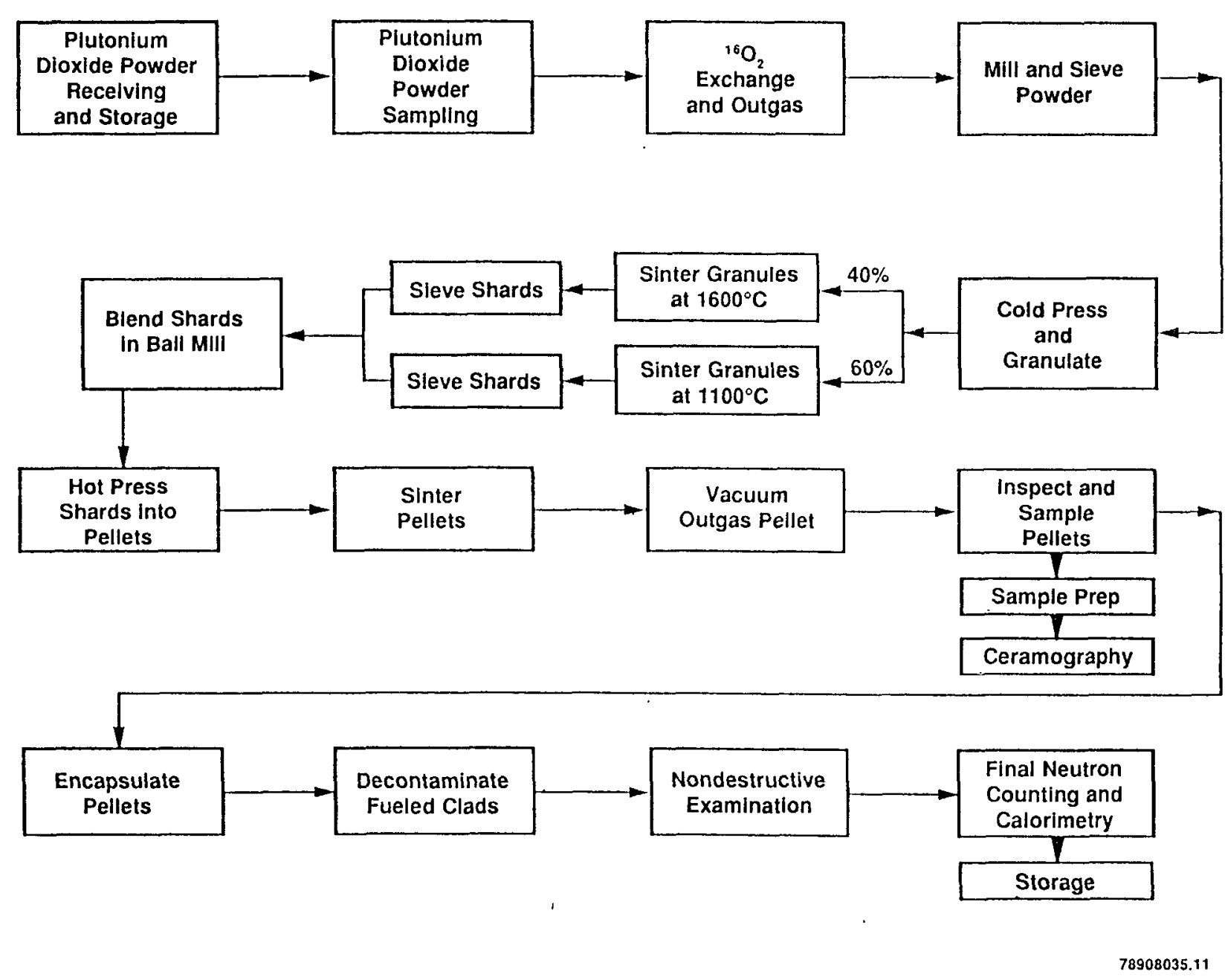

Figure 7. Overall Process Flow Diagram for the Fueled Clad Facility System. 
atmosphere containing oxygen, atomic weight 16 . Sixty percent of the granules will be sintered at $1100^{\circ} \mathrm{C}\left(2012^{\circ} \mathrm{F}\right)$, and $40 \%$ at $1600^{\circ} \mathrm{C}\left(2912^{\circ} \mathrm{F}\right)$. After sintering, the shards will be sieved to separate the agglomerated shards and recombined in a ball mill dedicated to shard blending.

The resulting granules will be transferred from cel1 145 to the hot pressing glovebox in room 141. The hot pressing ensures good control of pellet dimensions and microstructure. After being hot pressed, the pellets will be transferred to cell 144 where they will be sintered in a dedicated production furnace at $1525^{\circ} \mathrm{C}\left(2777^{\circ} \mathrm{F}\right)$, in an atmosphere containing oxygen, atomic weight 16 . The pellets will then be vacuum heat-treated in a sintering furnace at $1500^{\circ} \mathrm{C}\left(2732^{\circ} \mathrm{F}\right)$. The principal reason for the final sintering and outgassing operations is to ensure that the fuel pellet will remain dimensionally stable at expected operating temperatures. The sintering operation also burns off carbon introduced onto the pellet in the hot pressing operation and restores stoichiometry of the pellets to $238 \mathrm{PuO}_{2}$. The outgassing operation further removes volatile impurities such as helium. After heat treatment, the fuel pellets will be sampled. The samples will be prepared in cell 139 by grinding, polishing, mounting, and etching. After sample preparation, the pellets will be characterized by ceramography in cel1 142 .

The remaining pellets will be transferred to cell 143 after the heat treatment operation. In cell 143, pellets will be loaded into iridium capsules and the capsules will be welded shut in a helium atmosphere. The FCs will then be transferred to cell 137 for decontamination and nondestructive examination. Nondestructive examination will include ultrasonic testing of the capsule welds and helium leak checks.

\subsection{EMISSIONS CONTROL SYSTEM}

Because the radioactive airborne emissions from FCFS will consist primarily of particulate matter generated during the processing of the $238 \mathrm{PuO}_{2}$ powder (Section 5.0) the emissions control system must be capable of containing micrometer- and submicrometer-size particles.

As discussed in Section 3.0, the FCFS operations are provided with ventilation Zones I, II, and III with a negative pressure gradient from Zone III to Zone I to provide maximum confinement of radioactive contamination. Zone I gloveboxes will be operated at $-0.50 \pm 0.25 \mathrm{in}$. WG pressure relative to Zone II atmosphere. Zone I cells with manipulators will be operated at $-0.85 \pm 0.15$ in. WG pressure relative to Zone II atmosphere. Zone II will be operated at greater than -0.10 in. \pm 0.05 in. WG pressure relative to Zone III. Zone III will be operated at greater than - $0.10 \mathrm{in}$. WG relative to Zone IV (outside atmosphere).

Zone I ventilation areas in which radioactive materials are processed, use a recirculated argon atmosphere. Special sealed structures and structural penetrations are implemented to separate Zone I and Zone II areas. Zone I and Zone II exhausts are vented to separate primary high-efficiency 
particulate air (HEPA) filtration steps before being combined and routed to final filtration, consisting of three banks of HEPA filters, and finally discharged to the atmosphere. Zone III exhaust is ultimately routed with other plant exhausts to the final filtration step and discharged to the atmosphere.

Provision of both primary and final particulate control measures as described above allows for high-efficiency removal of particulates and provides system redundancy in the event of a failure of one of the emission control units. In addition, the FCFS Zone I cells are equipped with nontestable HEPA filters on both the inlet and outlet flows to minimize the radionuclide contamination of the connected atmosphere control systems.

\subsection{EMISSIONS RELEASE RATES}

The controlled release rates of particulate radionuclides from the FCFS were calculated based on an annual $238 \mathrm{PuO}_{2}$ throughput of $30 \mathrm{~kg}(66.1 \mathrm{lb})$ and using a release adjustment factor (RAF) of $2.5 \times 10^{-10}$.

The RAF assumes that $1 \%$ (the release factor) of the throughput material will become entrained in the cell atmosphere and pass through the ventilation system. (This is an extremely conservative assumption because there are non-testable HEPA filters between the cells, gloveboxes, hoods, and enclosures and the ventilation system. The HEPAs are $99.97 \%$ efficient upon installation. Therefore, for $1 \%$ of the entire throughput to become entrained in the ventilation system, over $100 \%$ of the entire throughput would have to be released.) The ventilation system is assumed to contain three HEPA filters in series, which is equivalent to a transmission factor of $2.5 \times 10^{-8}$. (It is also understood [McDowell et al. 1976] that where the aerosols are realistic in terms of what comes out of the facility, the recoil effect is not proven. In light of the possibility of the recoil effect, monitoring, appropriate filter changeouts, and other administrative controls will be implemented to ensure filter system integrity.) (As noted above, the hot cells, gloveboxes, hoods, and enclosures actually have an additional HEPA filter; however, this filter is not testable and the removal efficiency cannot be verified during operation. Therefore, no credit is taken for these filters in the dose calculations.) The RAF is the product of the release factor and the transmission factor. The projected controlled radioactive airborne particulate emissions releases for the FCFS are shown in Table 1-1.

Table 1-1. Controlled Particle Radionuclide Emission Rates for Fueled Clad Fabrication System ( $\mathrm{C} / \mathrm{yr}$ ) (Emissions at Stack).

Nuclide

$236 \mathrm{Pu}$

$238 \mathrm{Pu}$

$239 \mathrm{Pu}$

\section{Emission rate}

$2.79 E-08$

9.95 E-05

3.14 E-08 
DOE/RL 89-21

$240 \mathrm{Pu}$

$241 \mathrm{Pu}$

$242 \mathrm{Pu}$
$1.49 E-08$

$1.15 \mathrm{E}-05$

$4.39 E-10$

\subsection{OFFSITE DOSES}

The AIRDOSE-EPA (Clean Air Act Code) computer code was used to calculate the dose from FCFS to the maximally exposed offsite individual and thus demonstrate compliance with 40 CFR 61, Subpart H.

Meteorological data input to the AIRDOSE-EPA code include mixing height, rainfall rate, average air temperature, vertical temperature gradient, wind direction frequency, wind speed, and atmospheric stability. This information was obtained from the data base compiled by the Hanford Meteorological Station (HMS). The HMS data on airspeed, direction, and temperature are collected at a $124.9-\mathrm{m}(410-\mathrm{ft})$ tower located on the Hanford Site between the 200 East and 200 West Areas and at a second tower at the 400 Area. Wind speed and direction are based on hourly data collected at the 400 Area meteorological tower $10-\mathrm{m}(32.8-\mathrm{ft})$ level during the years 1983 to 1987 . Atmospheric stability was estimated from the temperature gradient between the $9.1-\mathrm{m}$ $(30-\mathrm{ft})$ and $60.9-\mathrm{m}(200-\mathrm{ft})$ levels at the HMS for the same period using standard methods of the U.S. Nuclear Regulatory Commission. Air temperature and mixing height are also 5-yr averages of hourly data. Temperature is measured at the tower $60.9-\mathrm{m}(200-\mathrm{ft})$ level, and mixing height data are collected by onsite acoustic sounders.

Joint frequency data, as reported by the HMS, are modified for input into AIRDOSE-EPA by conversion to true average and reciprocal average wind speeds for each direction and stability class. The meteorological data are then used to calculate $X / Q$ values for each radionuclide, which are also a function of radiological half-life and dry deposition velocity. For purposes of this calculation, deposition velocities are assigned as follows: $1.0 \times 10^{-3} \mathrm{~m} / \mathrm{s}$ for all particulate materials, $1.0 \times 10^{-2} \mathrm{~m} / \mathrm{s}$ for iodine isotopes, and zero for all gases.

Source Terms: Projected annual releases from FCFS as presented in Table 1-1.

Release Height: The FMEF stack height is $35.6 \mathrm{~m}(117 \mathrm{ft})$.

Inhalation Rate: $8,500 \mathrm{~m}^{3} / \mathrm{yr}\left(300,173 \mathrm{ft}^{3} / \mathrm{yr}\right)$.

Maximally Exposed Individual: Doses were estimated for an individual living $8.7 \mathrm{~km}(5.4 \mathrm{mi})$ south of the 427 Building.

Meteorology: The HMS data and onsite meteorological data, as discussed above.

Maximum individual doses were much less than $1 \mathrm{mR}$. Bone surface and lung were the organs receiving the highest dose, primarily from ${ }^{238} \mathrm{Pu}$. Inhalation was the dominant pathway for exposures. 
Table 1-2, shows the whole body and critical organ doses to the offsite individual receiving maximum exposure to airborne radiological emissions from the FCFS.

\author{
Table 1-2. Offsite Dose Estimates for an Individual \\ Receiving Maximum Exposure to Airborne Radiological \\ Emissions from Fueled Clad Fabrication System (mR). \\ Whole body \\ Critical organ \\ (bone surface) \\ 7.0 E-04 \\ $9.0 \mathrm{E}-03$
}

National ambient air quality standards for U.S. Department of Energy (DOE) facilities are stated in 40 CFR 61.92 as follows:

Emissions of radionuclides to air from DOE facilities shall not exceed those amounts that cause a dose equivalent of $25 \mathrm{mrem} / \mathrm{y}$ to the whole body or $75 \mathrm{mrem} / \mathrm{y}$ to the critical organ of any member of the public.

A comparison of the data presented in Table 1-2 with the cited statutory 1 imits shows that the projected whole body and critical organ doses of airborne radionuclides from the FCFS to the maximally exposed offsite individual would not violate federal standards.

Further, the Hanford Site Environmental Report for Calendar Year 1988, (Jacquish 1989) (a copy of which is available to the EPA on publication) states that the effective dose equivalent (whole body dose) to the maximally exposed offsite individual from all Hanford Site operations air emissions was $0.3 \mathrm{mR}$ in 1988. If the projected whole body dose from the FCFS as 1isted in Table 1-2 is added to the historic releases for 1988, it is clear that the FCFS projected emissions will not cause a violation of Federal standards. 


\section{REFERENCES}

Jacquish, R.E., 1989, Hanford Site Environmental Report for Calendar Year 1988, PNL-6825, Pacific Northwest Laboratories, Richland, Washington.

McDowell et al. 1976, Penetration of HEPA Filters by Alpha Recoil Aerosols, W. J. McDowell, and F.G. Seeley (Oak Ridge National Laboratory), and

M. T. Ryan (University of Lowe17, Massachusetts), 14th ERDA Air Cleaning Conference, Sun Valley, Idaho, August 11-13, 1976. 


\section{APPLICATION FOR APPROVAL OF CONSTRUCTION RADIOISOTOPE POWER SYSTEMS FACILITY}

\subsection{PROPOSED NATURE OF THE SOURCE}

The RPSF will join encapsulated plutonium oxide fuel pellets (fuel clads) with graphite aeroshells to form general purpose heat source (GPHS) modules (Figure 4). The GPHS modules will be grouped into various numbers and configurations to produce heat source assemblies (HSA). The HSAs will then be used in either radioisotope thermoelectric generators (RTG) (Figure 8) or dynamic isotope power systems (DIPS). The RTGs will be assembled in the RPSF. The DIPSs will assembled at another site.

\subsection{PROPOSED SIZE OF THE SOURCE}

The Radioisotope Power System Facility (RPSF) will be located in the Fuel and Materials Examination Facility (FMEF) Process Building on the $-5.2-\mathrm{m}$ $(17 \mathrm{ft})$ and $-10.7-\mathrm{m}(-35-\mathrm{ft})$ levels. Figures 9 and 10 detail those sections of the FMEF to be used by the RPSF.

The Process Building is a six-level, tornado-hardened, seismically qualified concrete structure $79.2 \mathrm{~m}(260 \mathrm{ft})$ long and $47.2 \mathrm{~m}$ (155 ft) wide,

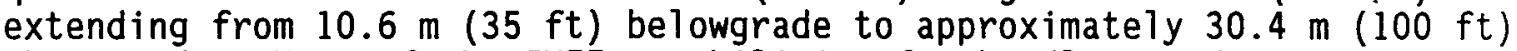
abovegrade. Most of the FMEF capabilities for handling radioactive materials are centered in the Process Building.

\subsection{PROPOSED DESIGN OF THE SOURCE}

The RPSF will be provided with ventilation Zones I, II, and III. Areas denoted Zone I will contain the radioactive materials being processed and will be separated from surrounding ventilation Zone II areas. Ventilation Zone III areas will be those support areas that bound ventilation Zone II. There will be a negative pressure gradient from Zone III to I so that any contaminants will flow into Zone I and through the facility emissions abatement systems. All Zone I air flows out the RPSF/FCFS stack. Figure 11 depicts RPSF cell air flow and indicates points of emission to the air.

Releases of radioactive materials to the ventilation system will occur in Zone I and may occur in Zone II. Releases of radioactive materials to the ventilation system from Zone III are unlikely. The RPSF activities taking place in each cell are summarized below. 


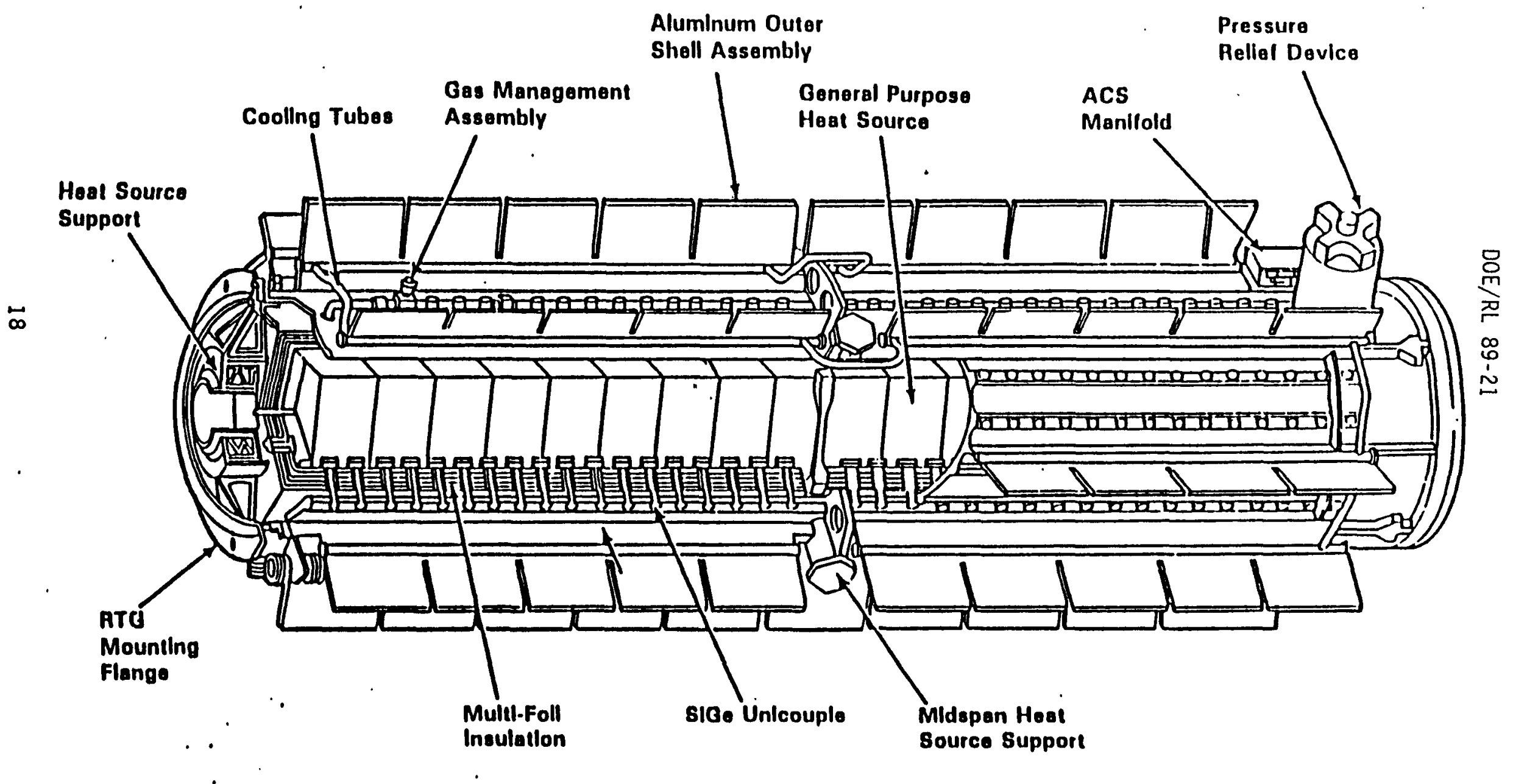

Figure 8. General Purpose Heat Source Radioisotope Thermoelectric Generator. 

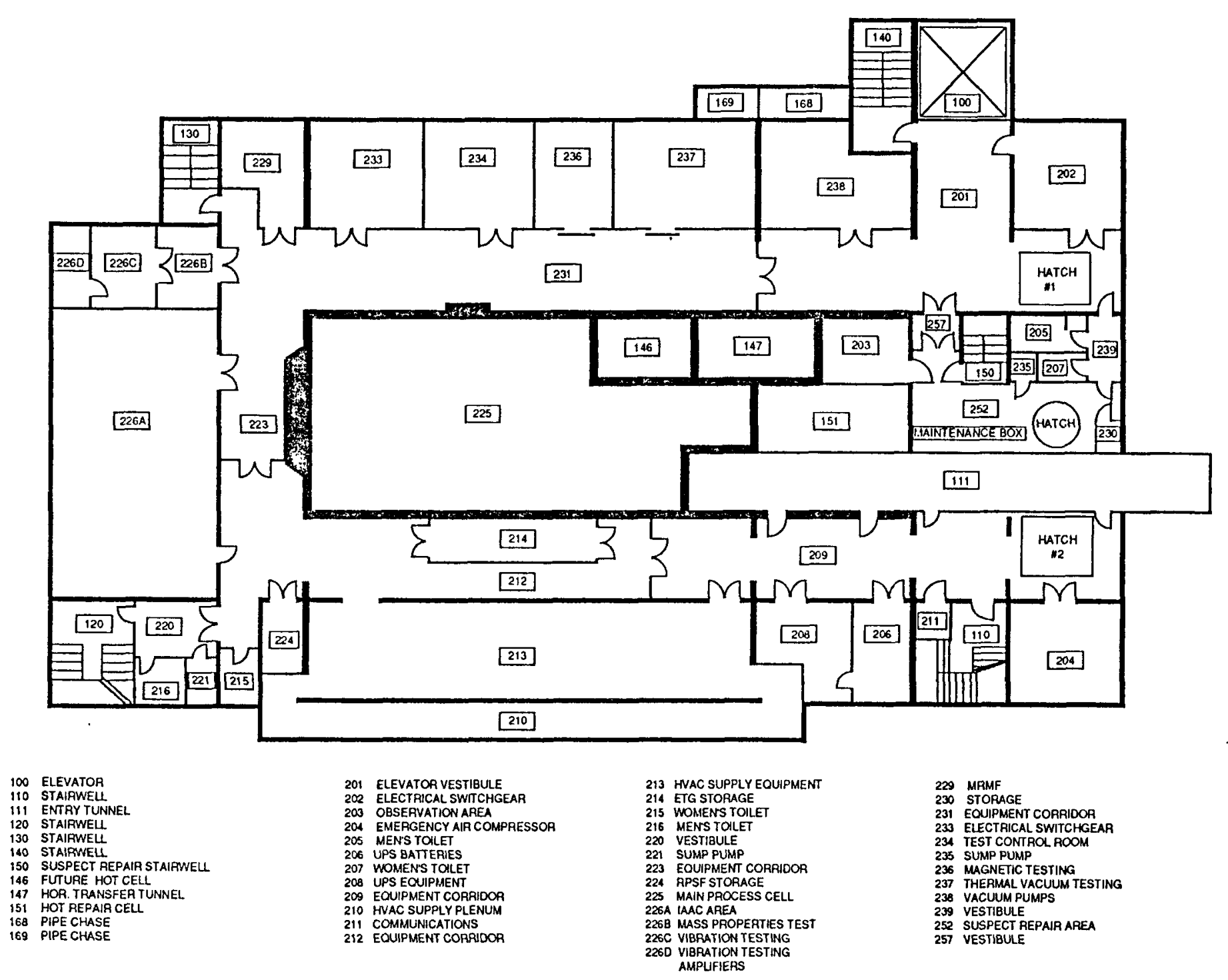

Figure 9. Radioisotope Power Systems Facility Floor Plan -5.2-Meters (-17-Feet) Elevation. 


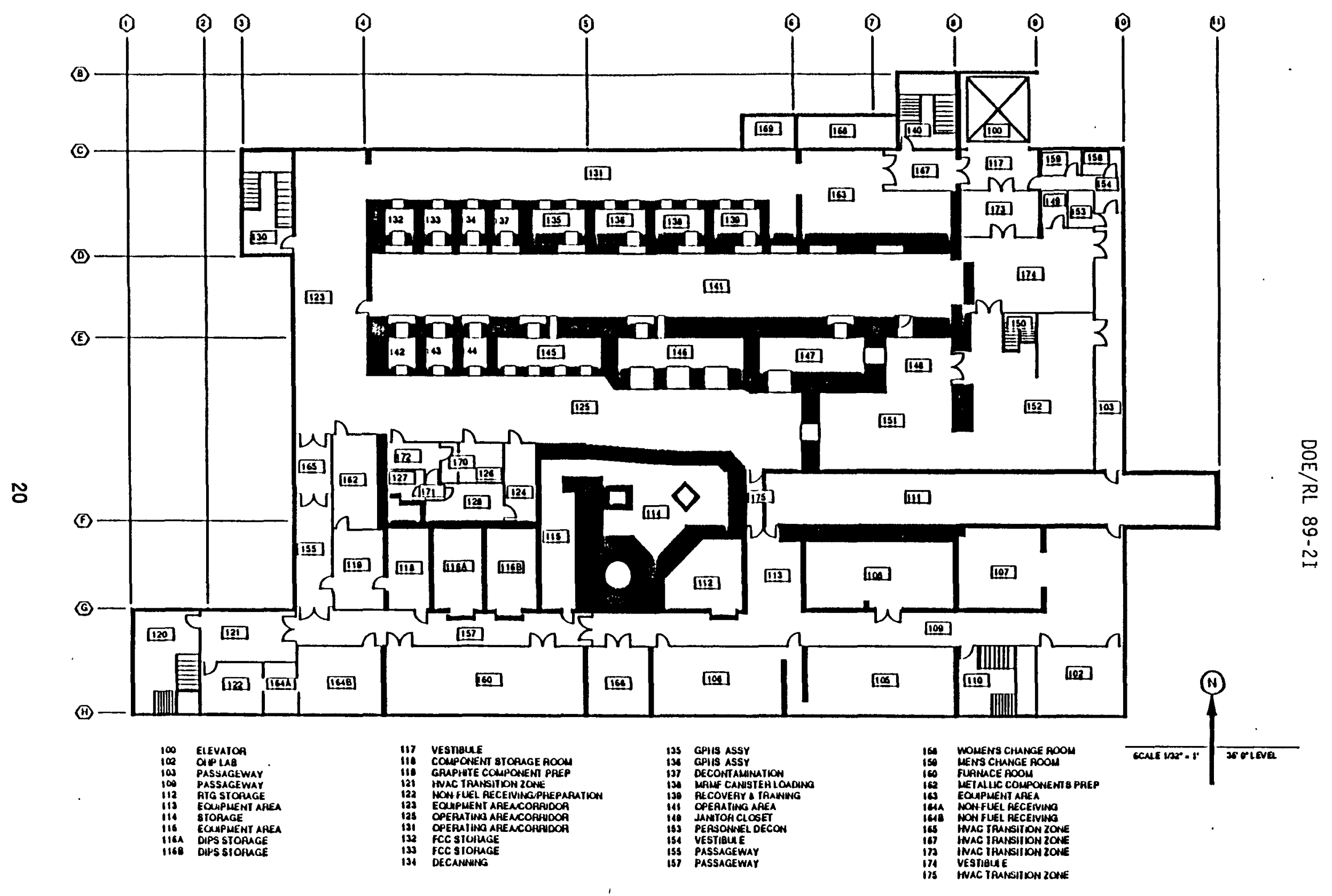

Figure 10. Radioisotope Power Systems Facility Floor Plan -10.7-Meters (-35-Feet) Elevation. 


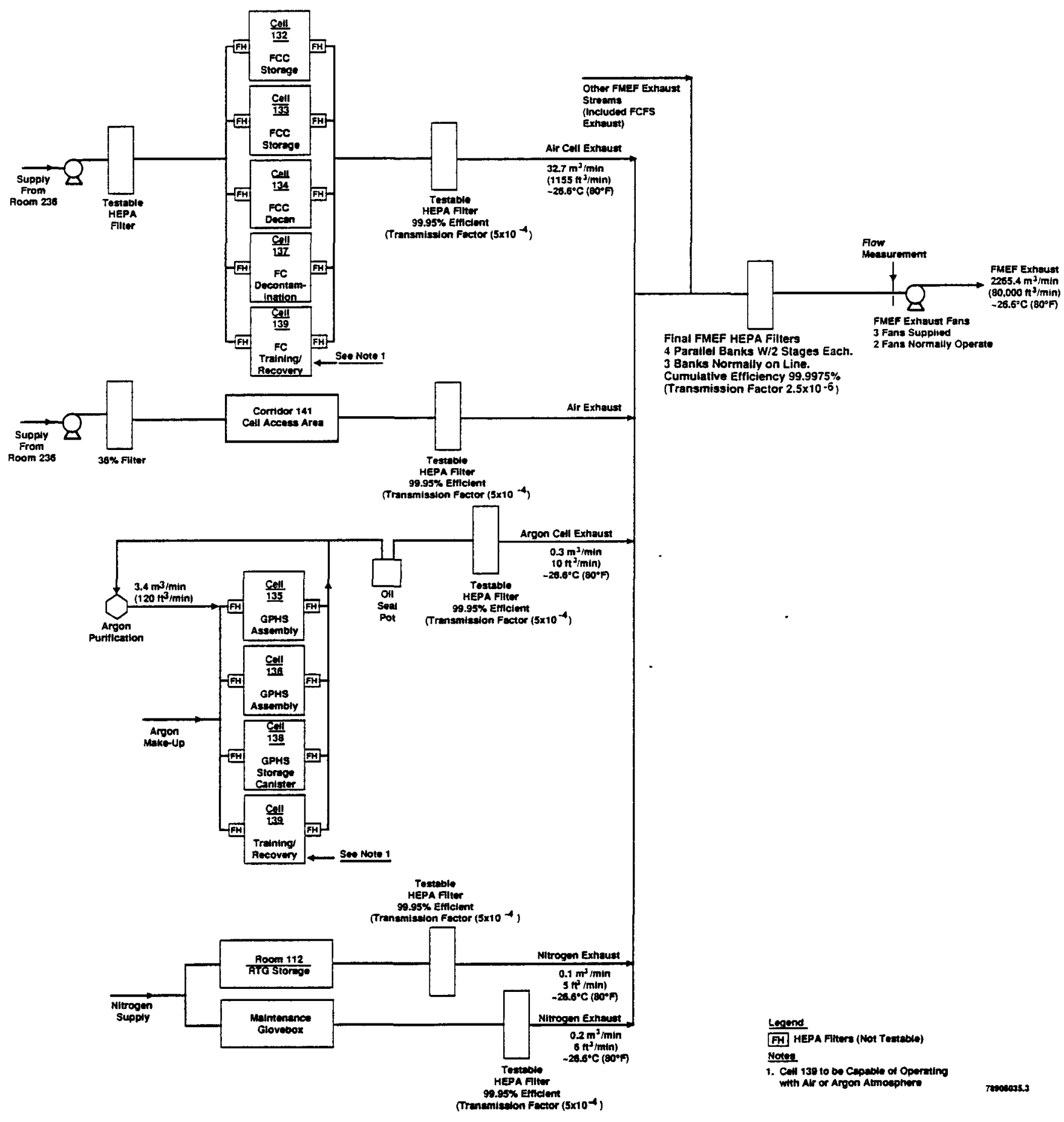

Figure 11. Radioisotope Power Systems Facility Ce11 Atmosphere Systems. 


\section{Zone I}

Cel1s 132, 133, 134, 135, 136, 137, and 138 will be part of the Zone I ventilation system. These enclosures will be used to assemble the FCs into GPHS modules. One percent of the plutonium dioxide contaminating the surface of the FCs is assumed to be released to the ventilation system during the assembiy process.

The exhausts from the inert atmosphere assembly chambers, room 112 , the room 229 vacuum pumps, and the room 237 thermal vacuum chambers will contain inert gases. These areas will be connected to the Zone I exhaust because of a concern for breathing air safety rather than radionuclide control.

\section{Zone II}

Rooms $123,125,131,141$, and 163 will be part of the Zone II ventilation system. Releases of radioactive materials to the Zone II ventilation system are not likely to occur because of the pressure differential between Zone II and Zone I, and there are backdraft dampers acting as check-valves between Zone II and Zone III.

\section{Zone III}

Zone III includes those areas surrounding the Zone II ventilation area. Releases of radioactive materials to the Zone III ventilation system are highly unlikely because of the negative pressure differential and because no radioactive materials will be stored or processed in Zone III. (Radioactive materials in transport containers will pass through Zone III to Zones I and II.)

\subsection{OPERATING DESIGN CAPACITY}

The RPSF will assemble GPHS modules $8 \mathrm{~h} / \mathrm{d}$ (one shift), $5 \mathrm{~d} / \mathrm{wk}, 52 \mathrm{wk} / \mathrm{yr}$, including maintenance downtime.

Production rates are stated in terms of GPHS modules. The normal production rate is 240 modules per year.

\subsection{METHOD OF OPERATION}

An overall process flow diagram is shown in Figure 12.

Assembly of the GPHS modules will take place in cells 135 and 136 of the RPSF. A sintered metal vent on four FCs will be activated and two FCs will then be inserted into a graphite sleeve. Two graphite sleeves will be inserted into the aeroshell to produce a GPHS module. The assembled GPHS modules will be transferred to cell.138 where they will be loaded into storage canisters, two GPHS modules into each canister, after which the canister 


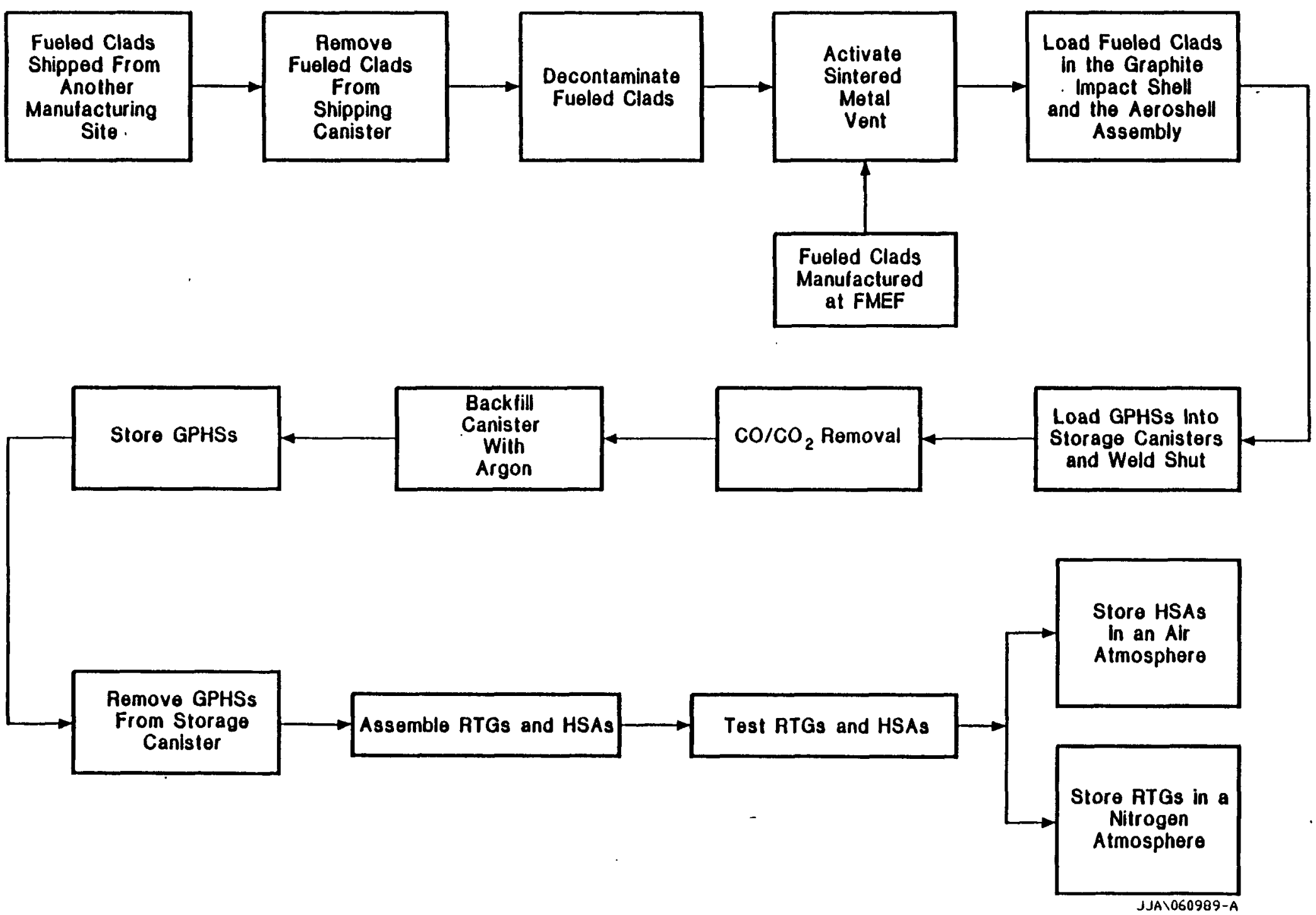

Figure 12. Overall Process Flow Diagram for Radioisotope Power Systems Facility. 
will be welded shut. Each storage canister will be equipped with an isolation valve and a tubing connector. The storage canisters will be transferred to room 229 where carbon monoxide and carbon dioxide contaminants are removed by successive evacuation and back filling of the storage canister with argon. (A beneficial side effect of this process is a slight reduction of the $\mathrm{PuO}_{2}$ to about $\mathrm{PuO}_{1.97 .)}$ ) The storage canisters will then be stored in room 229 until they are required for power source assembly.

Before assembly of the HSAs and the RTGs, the GPHS modules must be removed from their storage canisters. This operation will be performed in the decanning chamber in room 226A. The GPHS modules will then be assembled into HSAs and RTGs inside the inert atmosphere assembly chambers located in room 226A. Three inert atmosphere assembly chambers are planned to accommodate the variety of HSAs and RTGs to be produced in the RPSF. The chambers will contain an argon environment and each will have an argon purification system to control oxygen and moisture. Following assembly, the HSAs and RTGS will be tested as required by the specifications for that power source. The RPSF will have vibration testing, mass properties testing, magnetic properties testing, radiation mapping, and thermal vacuum testing capabilities.

Vibration testing will be provided in room $226 \mathrm{C}$ to subject the completed power sources to random, transient, and shock vibration loads along three discrete axial directions. Mass properties testing will be performed in room 226B. A computer-controlled floating spin table with load cells will be used to determine the center of gravity for the power source. The weight of the power source will also be determined. The magnetic field for the power source will be measured and, if necessary, adjusted in room 236 . Radiation mapping will be performed with portable instrumentation in the FMEF shipping and receiving area using instruments capable of measuring neutron flux, neutron energy spectra, gamma flux, and gamma energy spectra. Thermal vacuum testing will be performed in room 237 to determine the performance of the power source in simulated space conditions.

The completed HSAs and RTGs will be stored in the RPSF until they are ready to be used by the customer. Instrumentation to alarm off-normal conditions will be provided to monitor the RTGs and HSAs during storage. The RTGs will be stored in room 112. Room 112 will have a nitrogen atmosphere to minimize the deleterious effects of oxygen, carbon dioxide, and carbon monoxide on the thermoelectric components. The HSAs will be stored in rooms $116 \mathrm{~A}$ and $116 \mathrm{~B}$ until shipped off site to be joined with the generator systems. Rooms $116 \mathrm{~A}$ and $116 \mathrm{~B}$ will have an air atmosphere.

\subsection{EMISSIONS CONTROL SYSTEM}

Because the radioactive airborne emissions from RPSF will consist primarily of particulate matter generated during the assembly of GPHS modules, the emissions control system must be capable of containing micrometer-and submicrometer-size particles. 
As discussed in Section 3.0, the RPSF operations are provided with ventilation Zones I, II, and III with negative pressure gradient from Zone III to Zone I to provide maximum confinement of radioactive contamination. Zone I will be operated at $-1.00 \pm 0.25$ in. WG pressure relative to outside atmosphere. Zone II will be operated at $-0.25 \pm 0.05 \mathrm{in}$. WG pressure relative to outside atmosphere. Zone III will be operated at $-0.10 \pm 0.05 \mathrm{in}$. WG pressure relative to outside atmosphere.

Zone I ventilation areas in which the GPHS modules are assembled use a recirculated argon atmosphere while the remaining Zone I cells use an air atmosphere. Special sealed structures and structural penetrations are implemented to separate Zone I and Zone II areas. Zone I and Zone II exhausts are vented to separate primary high-efficiency particulate air (HEPA) filtration steps before being combined, and routed to final filtration consisting of three banks of HEPA filters, and discharged to the atmosphere (Figure 12). Zone III exhaust is ultimately routed with other plant exhausts to the final HEPA filtration step and discharged to the atmosphere.

Provision of both primary and final particulate control measures, as described above, allows for high-efficiency removal and provides system redundancy in the event of a failure of one of the emission control units. In addition, the RPSF Zone I cells are equipped with non-testable HEPA filters on both the inlet and outlet flows to minimize the radionuclide contamination of the connected atmosphere control systems.

\subsection{EMISSIONS RELEASE RATES}

The controlled release rates for radionuclides from the RPSF were calculated based on an annual throughput of $960 \mathrm{FCs}$. Because the FCs have been decontaminated for shipping purposes, the surface contamination is estimated to be only $8.6 \times 10^{-6} \mathrm{Ci} / \mathrm{yr}$. (Shipping requirements are no more than $20,000 \mathrm{dpm} / \mathrm{FC}$. There are $4.5 \times 10^{-13} \mathrm{Ci} / \mathrm{dpm}$, and there are $\left.960 \mathrm{FCs}.\right) \mathrm{A}$ release adjustment factor (RAF) of $2.5 \times 10^{-10}$ was then applied to the $8.6 \times 10^{-6} \mathrm{Ci} / \mathrm{yr}$.

The RAF assumes that $1 \%$ (the release factor) of the PuO $0_{2}$ powder contaminating the capsule surfaces will become entrained in the cell atmosphere and pass into the ventilation system. (This is an extremely conservative assumption because there are non-testable HEPA filters between the gloveboxes and the ventilation system. The HEPAs are $99.97 \%$ efficient upon installation. Therefore, for $1 \%$ of the entire throughput to become entrained in the ventilation system, over $100 \%$ of the entire throughput would have to be released.) The ventilation system is assumed to contain three HEPA filters in series, which is equivalent to a transmission factor of $2.5 \times 10^{-8}$. (It is understood that aggregate recoil particles from a source of alpha activity appear to penetrate HEPA filters much more effectively than would be expected on the basis of filter efficiency for similar sized stable aerosols. It is also understood [McDowell et al. 1976] that where the aerosols are realistic in terms of what comes out of the facility, the recoil 
effect is not proven. In light of the possibility of the recoil effect, monitoring, appropriate filter changeouts, and other administrative controls wi11 be implemented to ensure filter system integrity.) The RAF is the product of the release factor and the transmission factor. For purposes of the dose calculation, the RPSF is assumed to contain only three HEPA filters in series. The golveboxes, hoods, and enclosures actually have an additional HEPA filter; however, this filter is not testable, and the removal efficiency cannot be verified during operation. Therefore, no credit is taken for these HEPA filters in the dose calculations. The particulate radionuclide emission rates for the RPSF are shown in Table 2-1.

Table 2-1. Controlled Particle Radionuclide Emission Rates for Radioisotope Power System Facility $(\mathrm{Ci} / \mathrm{yr})$ (Emissions at Stack).

Nuclide

$236 \mathrm{Pu}$

$238 \mathrm{Pu}$

$239 \mathrm{Pu}$

$240 \mathrm{Pu}$

$241 \mathrm{Pu}$

$242 \mathrm{Pu}$
Emission rate

$5.58 E-19$

$1.99 \mathrm{E}-15$

$6.27 E-19$

$2.98 \mathrm{E}-19$

2.30 E-16

$8.77 \mathrm{E}-21$

\subsection{OFFSITE DOSES}

The AIRDOSE-EPA (Clean Air Act Code) computer code was used to calculate the dose from RPSF to the maximally exposed offsite individual, and thus demonstrate compliance with 40 CFR 61, Subpart $H$.

Meteorological data input to the AIRDOSE-EPA code include mixing height, rainfall rate, average air temperature, vertical temperature gradient, wind direction frequency, wind speed, and atmospheric stability. This information was obtained from the data base compiled by the Hanford Meteorological Station (HMS). The HMS data on airspeed, direction, and temperature are collected at a $124.9-\mathrm{m}(410-\mathrm{ft})$ tower located on the Hanford Site between the 200 East and 200 West Areas, and at a second tower at the 400 Area. Wind speed and direction are based on hourly data collected at the 400 Area meteorological tower 10-m (32.8-ft) Tevel during the years 1983 to 1987 . Atmospheric stability was estimated from the temperature gradient between the $9.1-\mathrm{m}$ $(30-\mathrm{ft})$ and $60.9-\mathrm{m}(200-\mathrm{ft})$ levels at the HMS for the same period using standard methods of the U.S. Nuclear Regulatory Commission. Air temperature and mixing height are also 5-yr averages of hourly data. Temperature is measured at the tower $60.9-\mathrm{m}(200-\mathrm{ft})$ level, and mixing height data are collected by onsite acoustic sounders.

Joint frequency data as reported by the HMS are modified for input into AIRDOSE-EPA by conversion to true average and reciprocal average wind speeds for each direction and stability class. The meteorological data are then 
used to calculate $X / Q$ values for each radionuclide, which are also a function of radiological half-life and dry deposition velocity. For purposes of this calculation, deposition velocities are assigned as follows: $1.0 \times 10^{-3} \mathrm{~m} / \mathrm{s}$ for all particulate materials, $1.0 \times 10^{-2} \mathrm{~m} / \mathrm{s}$ for iodine isotopes, and zero for all gases.

Source Terms: Projected annual releases from RPSF as presented in Table 2-1. Release Height: The FCFS/RPSF stack height is $35.6 \mathrm{~m}(117 \mathrm{ft})$.

Inhalation Rate: $8,500 \mathrm{~m}^{3} / \mathrm{yr}\left(300,173 \mathrm{ft}^{3} / \mathrm{yr}\right)$.

Maximally Exposed Individual: Doses were estimated for an individual living $8.7 \mathrm{~km}(5.4 \mathrm{mi})$ south of the 427 Building.

Meteorology: The HMS data and onsite meteorological data, as discussed above.

Maximum individual doses were much less than $1 \mathrm{mR}$. Bone surface and lung were the organs receiving the highest dose, primarily from $238 \mathrm{Pu}$. Inhalation was the dominant pathway for exposures.

Table 2-2, shows the whole body and critical organ doses to the offsite individual receiving maximum exposure to airborne radiological emissions from the RPSF.

Table 2-2. Offsite Dose Estimates for an Individual Receiving Maximum Exposure to Airborne Radiological Emissions from Radioisotope Power System Facility (mR).

Whole body $1.4 \mathrm{E}-14$
Critical organ (bone surface)

$1.8 \mathrm{E}-13$

National ambient air quality standards for U.S. Department of Energy (DOE) facilities, are stated in 40 CFR 61.92 as follows:

Emissions of radionuclides to air from DOE facilities shall not exceed those amounts that cause a dose equivalent of $25 \mathrm{mrem} / \mathrm{y}$ to the whole body or $75 \mathrm{mrem} / \mathrm{y}$ to the critical organ of any member of the public.

A comparison of the data presented in Table 2-2 with the cited statutory limits clearly shows that the projected whole body and critical organ doses of radionuclides to the offsite individual receiving maximum exposure to airborne radiological emissions from the RPSF will not violate Federal standards. 
Further, the Hanford Site. Environmental Report for Calendar Year 1988, (Jacquish 1989), a copy of which is available to the EPA on publication, states that the effective dose equivalent (whole body dose) to the maximally exposed offsite individual from all Hanford Site operations air emissions was $0.3 \mathrm{mR}$ in 1988. If the projected whole body dose, as 1isted in Table 2-2, from the RPSF to the maximally exposed offsite individual is added to the historic releases for 1988 , it is clear that the RPSF projected emissions will not cause a violation of Federal standards. 


\section{REFERENCES}

Jacquish, R.E., 1989, Hanford Site Environmental Report for Calendar Year 1988, PNL-6825, Pacific Northwest Laboratories, Richland, Washington.

McDowe11 et al. 1976, Penetration of HEPA Filters by Alpha Recoi7. Aerosols, W. J. McDowe11, and F.G. Seeley (Oak Ridge National Laboratory), and M. T. Ryan (University of Lowe11, Massachusetts), 14th ERDA Air Cleaning Conference, Sun Valley, Idaho, August 11-13, 1976. 


\section{APPLICATION FOR APPROVAL OF CONSTRUCTION \\ FUEL ASSEMBLY AREA}

\subsection{PROPOSED NATURE OF THE SOURCE}

The Fuel Assembly Area (FAA) will process special nuclear materials. The FAA will fabricate and store enriched uranium oxide driver fuel and neptunium oxide target pins for the Fast Flux Test Facility (FFTF). At a later date, mixed uranium plutonium oxide (MOX) fuel may be processed within FAA.

\subsection{PROPOSED SIZE OF THE SOURCE}

The Fuel Assembly Area (FAA) will be located in Building 4862 of the Fuels and Materials Examination Facility (FMEF) (Figure 3 ). Figure 13 depicts the layout of the FAA within Building 4862 .

The Fuel Assembly Area (FAA) is a two-story tornado hardened, seismically qualified structure $54.8 \mathrm{~m}(180 \mathrm{ft}) 1 \mathrm{ong}, 39.6 \mathrm{~m}(130 \mathrm{ft})$ wide, and $7.9 \mathrm{~m}$ (26 ft) high, housing FFTF fuel and target fabrication assembly activities.

\subsection{PROPOSED DESIGN OF THE SOURCE}

The FAA will be provided with ventilation Zones I, II, III, IV, and airlocks, as required, for zone separation in high-traffic access areas. Areas denoted Zone I will contain the unencapsulated radioactive materials being processed and will be separated from surrounding ventilation Zone II areas. Ventilation Zone II areas will process encapsulated radioactive materials and will bound Zone I. Ventilation Zone III will contain of "a" and "b" areas. Ventilation Zone IIIa areas will bound Zone II and will be those areas in which encapsulated radioactive materials are handled. Ventilation Zone IIIb areas will be buffer zones and will not contain radioactive materials. Ventilation Zone IV will be at atmospheric pressure and will not contain any radioactive materials.

There will be a negative pressure gradient from Zone III to II to I so that any contaminants will flow into Zone $I$ and through the facility emissions abatement systems. All Zone I air flows out the FAA stack. Figure 14 depicts FAA cell air flow and indicates points of emission to the air. 


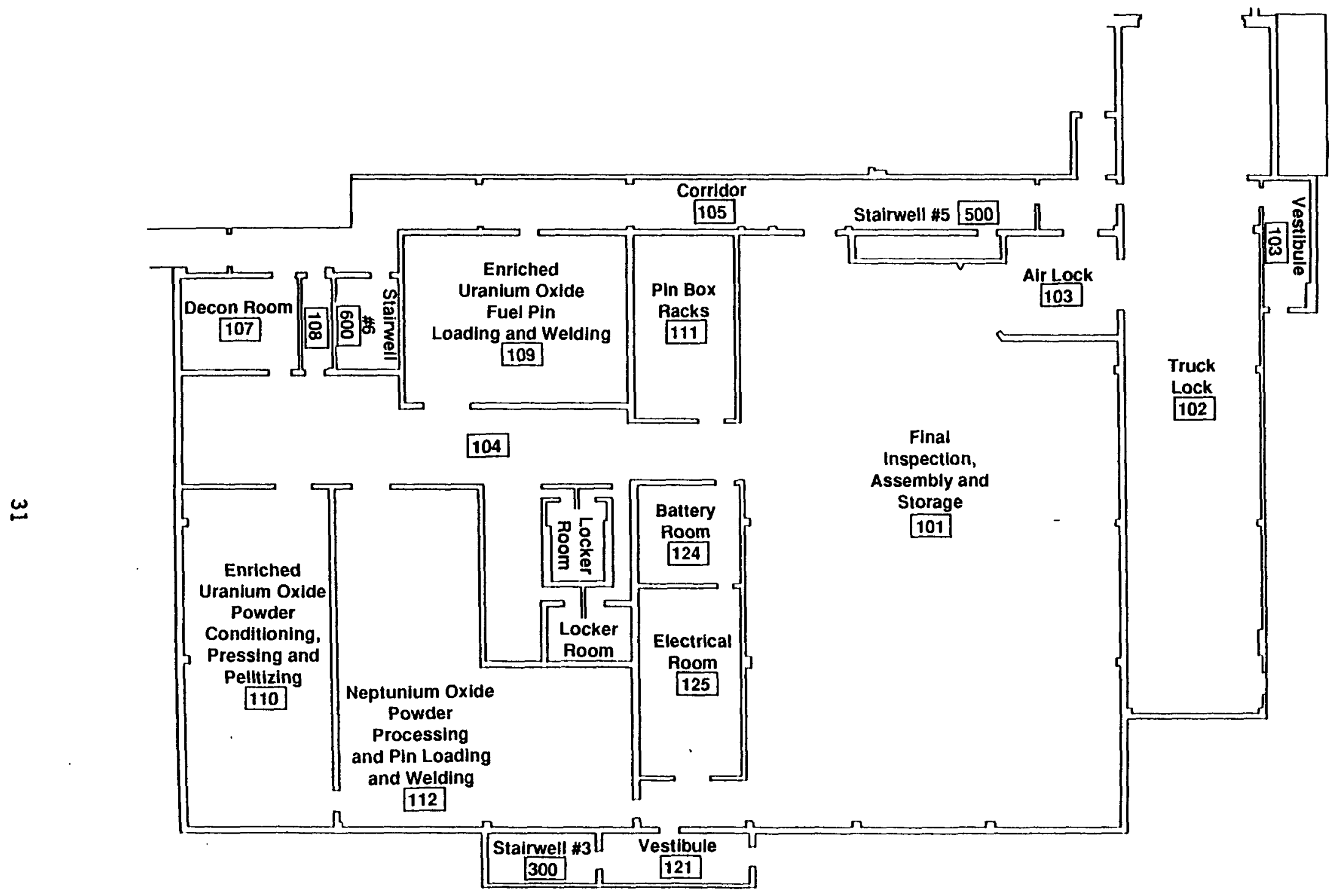

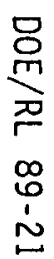

Figure 13. Fuel Assembly Area Floor Plan. 


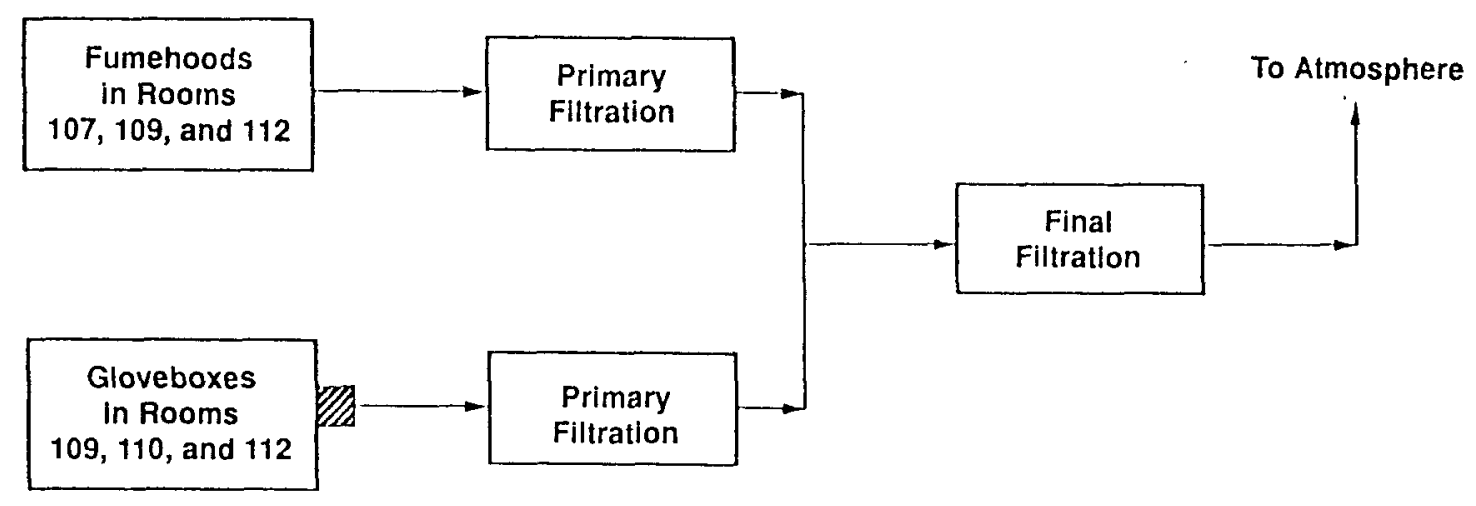

WO Non-Testable HEPA - One Filter is Located on Outlet of Each Glovebox.

Figure 14. Fuel Assembly Area Zone I Exhaust Flow Diagram. 


\section{Zone I}

Gloveboxes in rooms 109,110 , and 112 and open-faced hoods in rooms 107 109, and 112 will be part of the Zone I ventilation system. These enclosures will be used in the processing of uranium dioxide and neptunium oxide powder into pellets and in the encapsulation of these pellets into pins, as described in Section 5.0, below. Releases of radioactive materials to the ventilation system will occur in Zone I.

\section{Zone II}

Rooms 104, 107, 109, 110, and 112 will be part of the Zone II ventilation system. Releases of radioactive materials to the Zone II ventilation system are not likely to occur because the processing of unencapsulated radioactive materials are performed only in Zone I areas and because of the pressure differential between Zone II and Zone I.

\section{Zone II I}

Rooms 101, 274, and 279 and shall be Zone IIIa. Rooms 108, 271, 276, 277, and 278 and corridors 105 and 272 shall be Zone IIIb. Releases of radioactive materials to the Zone III ventilation system are highly unlikely because these rooms will not contain any unencapsulated radioactive materials.

\section{Zone IV}

Rooms 124, 125, and 102 will be at atmospheric pressure and wil] thus be considered part of Zone IV. Releases of radioactive materials will not take place in Zone IV because no radioactive materials will be handled in those areas.

\subsection{OPERATING DESIGN CAPACITY}

The FAA will fabricate fuel pins $8 \mathrm{~h} / \mathrm{d}$ (one shift), $5 \mathrm{~d} / \mathrm{wk}, 44 \mathrm{wk} / \mathrm{yr}$, not including maintenance down-time.

Production rates are stated in terms of fuel pins. The normal production rate is approximately 11,000 fuel pins per year.

\subsection{METHOD OF OPERATION}

A process flow diagram for the production of the enriched uranium oxide driver fuel is shown in Figure 15. A process flow diagram for the neptunium oxide target pin fabrication and storage is shown in Figure 16. 


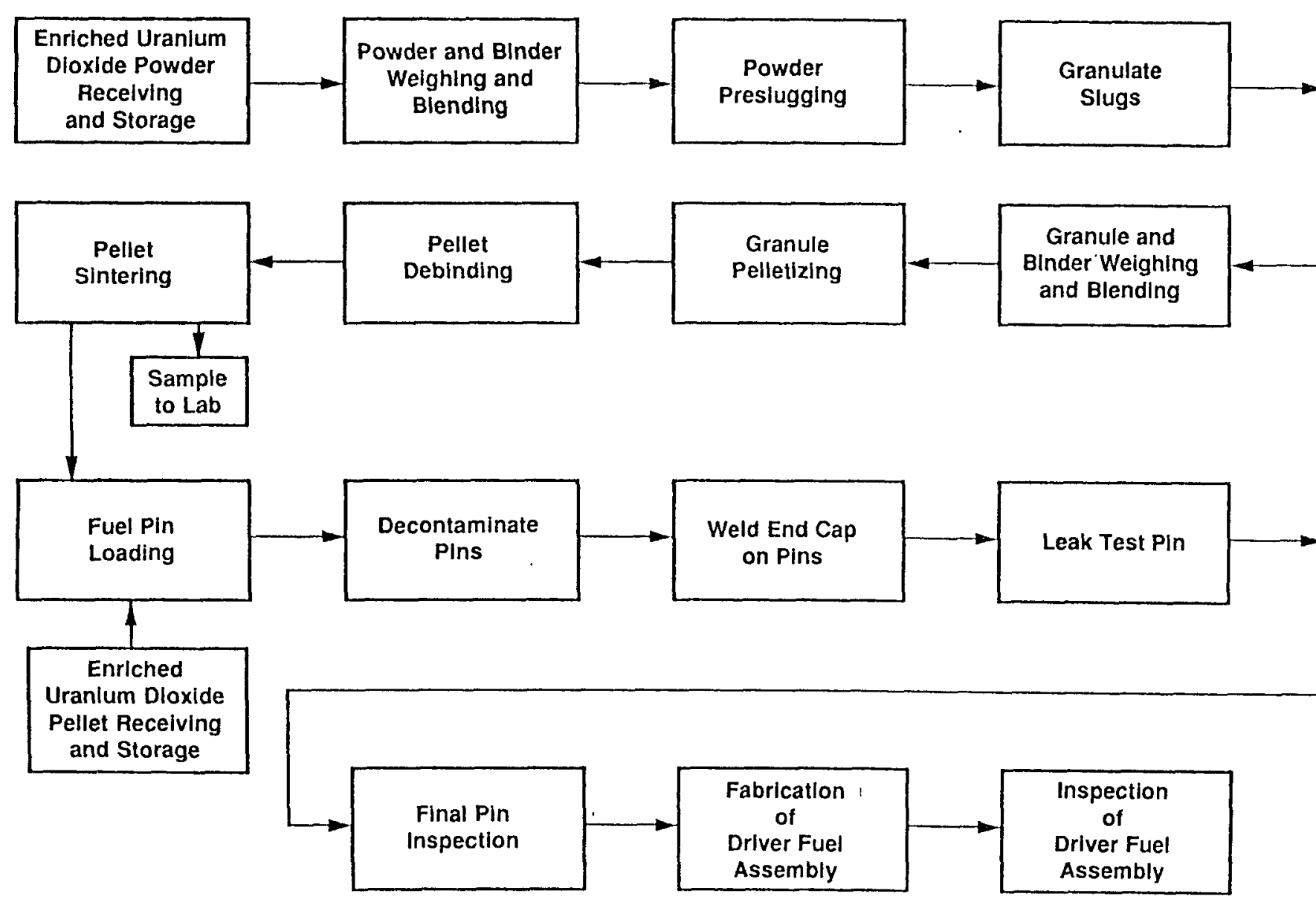

78908035.12

Figure 15. Overall Process Flow Diagram for Enriched Uranium 0xide Driver Fuel Fabrication. 


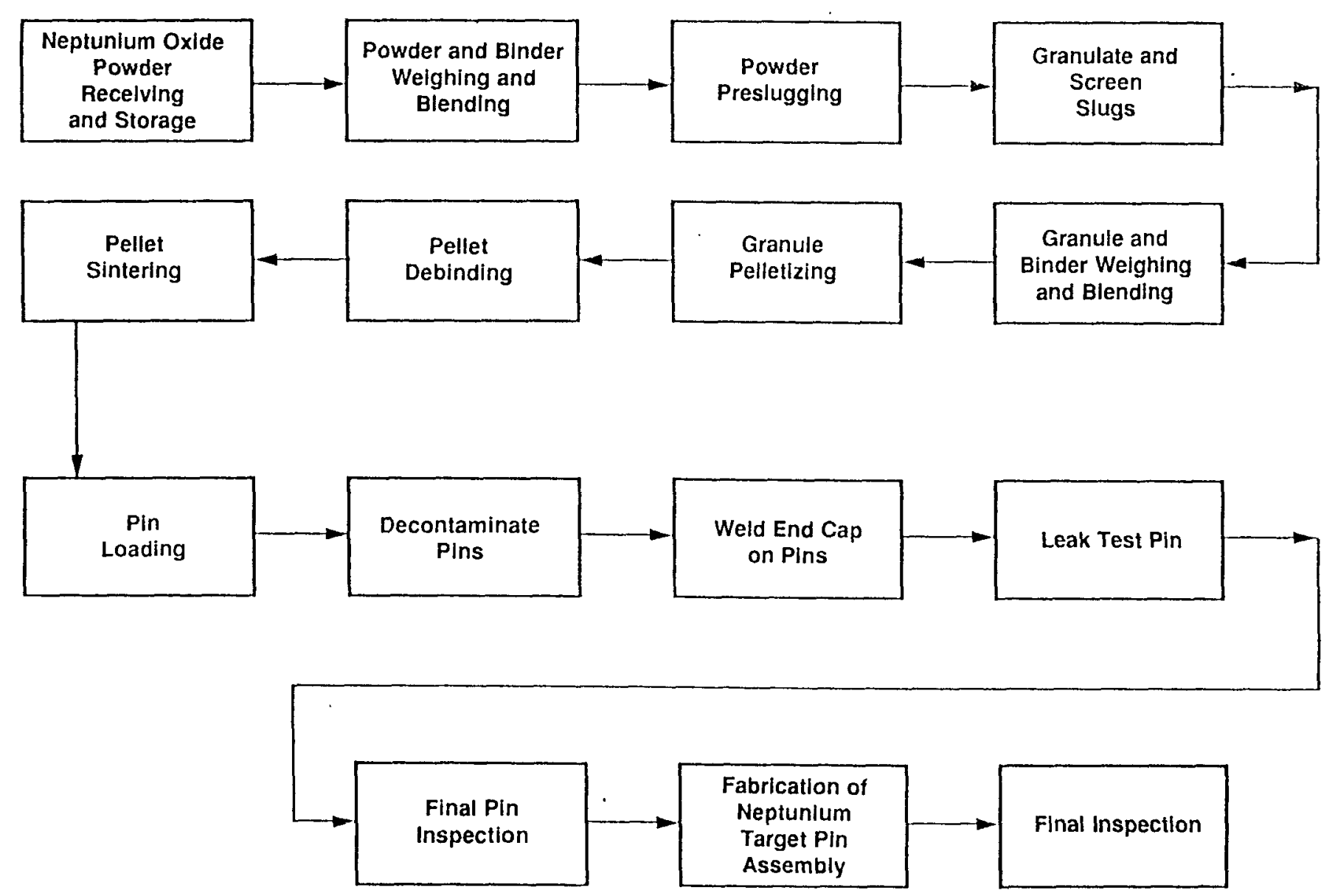


Because the production of MoX fuel (Section 1.0) will use basically the same process as the enriched uranium, and because the enriched uranium will be the initial fuel processed, the following process description refers only to enriched uranium, though it is applicable to MOX.

\section{Enriched Uranium Oxide Driver Fuel Fabrication}

Shipments of powder and pellets will be received in standard shipping containers. The containers will be unloaded and transferred to the high bay area (room 101) and stored until they can be unloaded. From room 101, the containers will be transferred to rooms 104, 107, or 109 for unloading.

Inside the container will be a sealed fuel shipping canister, which contains the powder or pellets. The fuel shipping canisters will be removed from the containers. Within each canister will be up to four cans, each containing approximately $1 \mathrm{~kg}(2.2 \mathrm{lb})$ fissile powder, or two cans, each containing approximately $2.5 \mathrm{~kg}(5.5 \mathrm{lb})$ fissile pellets. The cans will be removed, surveyed, cleaned, and processed through nondestructive assay. The cans will then be transferred to room 110 for storage.

The first major process step will be powder conditioning and pressing. Within the pressing enclosures in room 110, powder and binder will be weighed and blended; blended powder will be preslugged; slugs will be granulated; and granules and binder will be weighed, blended, and repackaged in cans for storage or transfer to the next operation. The granule-binder mixture will then be pelletized and transferred to the sintering/debind enclosure. Three single-cavity presses will be available for performing the preslugging and pelletizing.

Within the sintering/debind enclosure in room 110, the pellets will be loaded into a furnace for debinding and will then be loaded into a second furnace for sintering. Once the pellets have been removed from the sintering furnace, some will be sent to a laboratory for analysis. The remaining pellets will be repackaged in cans and returned to storage in room 110 .

Pellets will be transferred from storage to the fuel pin loading glovebox in room 109. At this station, the fuel pellets will be visually inspected, the fuel annulus verified, the fuel column assembled, and the fuel column and other pin internal components loaded into the fuel cladding. After loading, the top end of the fuel pin cladding will be cleaned to reduce gross contamination and the end of the cladding will be sealed and surveyed. The loaded pins will then be placed in a pin box for transfer to room 107 . In room 107, the pin will undergo further decontamination. The decontaminated pins will be resealed, placed back into the pin box and returned to room 109 for end cap final closure weld.

There the pins will be placed in an evacuation chamber and the temporary plug will be removed. The chamber will be evacuated and backfilled in rapid succession until all of the air has been replaced with helium fill-gas. The chamber will then be opened to the weld enclosure and the tag gas capsule and top end cap will be inserted and the top end cap welded to the cladding. 
The pins will then be removed from the welding enclosure and taken to the leak-test enclosure, also located in room 109. The pins will then either be transferred to room 111 for storage or processed through final inspection.

Final inspection operations will be performed in room 101, and will include tag gas rupture, $X$-radiography, fuel-enrichment verification, $p$ in workmanship, final visual inspection, end cap drill, and wire wrap.

When pins are ready for assembly into the driver fuel, they will be taken to the final assembly table in room 101. Here, the individual pins will be assembled into pin bundles (217 pins per bundle). The pin bundles will then be inspected. After inspection, the pin bundles will be transferred to the assembly pit where the direct-handling subassembly will be lowered over the pin bundle. The pin bundle will then be returned to the assembly table and the duct welded to the shield inlet assembly. The weld will be examined and a final wipe of the assembly will be taken. Final inspection of the driver fuel assembly will include an air flow test and weight and center of gravity measurements. After all standard inspection and measurements are performed, the assembly will be returned to the storage pit or prepared for shipment.

\section{Neptunium 0xide Target Pin Fabrication}

The neptunium oxide will be transferred from storage in room 101 to the target pin fabrication line in room 112. If necessary, the powder will be milled and screened to meet feed powder specifications. The powder will be mixed with binder in a blender and will then be preslugged in a cold press. The slugs will be granulated and screened. The resulting granules will be mixed with binder in a blender and pressed into pellets. The pellets will be transferred to a furnace for debinding and then to a second furnace for sintering. After sintering, the pellets will be inspected for conformance to specifications. The pellets conforming with specifications will be stored temporarily before being sent to target pin fabrication. Pellets not meeting specifications will be ground into powder to be used to make new pellets.

From temporary storage, cans of pellets will be transferred to the pin loading area of room 112. The pellets will be removed from the cans and loaded into the pin. The pin will then be decontaminated at the loading station in room 107. When decontamination has been completed, the pin will be transported to the welding station in room 112 for the final closure weld. The assembled pins will be leak tested before storage. Final operations on the pins will be performed in room 101 and will include tag gas rupture, weld X-radiography, inspection, pin workmanship, and final visual inspection.

When pins are ready for fabrication into neptunium target pin assemblies, they will be taken to the final assembly station in room 101 . Here, the individual pins will be inserted into pin bundles. The assembled neptunium pin bundles will then be stored in the storage pit in room 101 . 


\subsection{EMISSIONS CONTROL SYSTEM}

Because the radioactive airborne emissions from FAA will consist primarily of particulate matter generated during the processing of $\mathrm{EuO}_{2}$ and $237 \mathrm{~Np}$ oxide powders (Section 5.0) the emissions control system must be capable of containing micrometer- and submicrometer-size particles.

As discussed in Section 3.0, the FAA operations are provided with ventilation Zones I, II, and III with a negative pressure gradient from Zone III to Zone I to provide maximum containment of radioactive contamination. All powder handling operations will take place in Zone I gloveboxes. Zone I gloveboxes shall be operated at -0.55 to -0.75 in. WG pressure relative to outside atmosphere. Zone II shall be operated at -0.20 to $-0.30 \mathrm{in}$. WG pressure relative to outside atmosphere. Zone IIIa radiological operating and equipment areas shall be operated at -0.05 to -0.15 in. WG pressure relative to outside atmosphere. Zone IIIb shall be operated at -0.05 to $-0.10 \mathrm{in}$. WG pressure relative to outside atmosphere, Zone IV.

Zone I ventilation areas draw air from the surrounding Zone II rooms. Figure 15 shows FAA Zone I exhaust flow. Zone II ventilation areas use a recirculated air atmosphere. Special sealed structures and structural penetrations are implemented to separate Zone I and Zone II areas. Zone I and Zone II exhausts are vented to separate primary filtration steps before being combined, routed to final filtration, and discharged to the atmosphere. Some Zone III exhaust is routed directly to Zone II areas to supply ventilation air to Zone II. The remainder of Zone III exhaust is ultimately routed along with other plant exhausts to a single final filtration step and discharged to the atmosphere.

The exhaust from the FAA process operations will be provided with both primary and final particulate control measures as described above. This allows for high-efficiency removal and provides system redundancy in the event of a possible failure of one of the emission control units. In addition, the gloveboxes (Zone I) are equipped with non-testable HEPA filters on both the inlet and outlet flows to minimize the radionuclide contamination of the connected atmosphere control systems. The fumehoods in rooms 107, 109, and 112 will not be equipped with non-testable HEPAs because the distance to the testable HEPAs is relatively short.

After primary treatment, all the exhaust from FAA operations is combined and routed to a final filtration step consisting of three banks of HEPA filters before discharge through the main building stack.

Provision of both primary and final particulate control measures, as described above, allows for high-efficiency removal of particulates and provides system redundancy in the event of a possible failure of one of the emission control units. 


\subsection{EMISSIONS RELEASE RATES}

The projected controlled emission rates of particulate radionuclides for the FAA were calculated based on an annual MOX throughput of $100 \mathrm{~kg}$ $(220.4 \mathrm{lb})$, an annual enriched uranium oxide throughput of $1,850 \mathrm{~kg}(4,078$ 1b), an annual ${ }^{237} \mathrm{~Np}$ oxide throughput of $115 \mathrm{~kg}(253.5 \mathrm{lb})$ and using a release adjustment factor (RAF) of $2.5 \times 10^{-10}$. Though the MOX fuel and enriched uranium fuel will not be processed simultaneously, complete annual campaigns for both fuels were used as source terms in order to permit the change-over from one fuel to the other.

The RAF assumes that $1 \%$ (the release factor) of the throughput material will become entrained in the cell atmosphere and pass through the ventilation system. (This is an extremely conservative assumption because there are non-testable HEPA filters between the gloveboxes and the ventilation system. The HEPAs are $99.97 \%$ efficient upon installation. Therefore, for $1 \%$ of the entire throughput to become entrained in the ventilation system, over $100 \%$ of the entire throughput would have to be released.) The ventilation system is assumed to contain three HEPA filters in series, which is equivalent to a transmission factor of $2.5 \times 10^{-8}$. (It is understood that aggregate recoil particles from a source of alpha activity appear to penetrate HEPA filters much more effectively than would be expected on the basis of filter efficiency for similar sized stable aerosols. It is also understood [McDowell et a]. 1976] that where the aerosols are realistic in terms of what comes out of the facility, the recoil effect is not proven. In light of the possibility of the recoil effect, monitoring, appropriate filter changeouts, and other administrative controls will be implemented to ensure filter system integrity.) (As noted above, the gloveboxes actually have an additional HEPA filter; however, because this filter is not testable and the removal efficiency cannot be verified during operation, no credit is taken for these filters in the dose calculations.) The RAF is the product of the release factor and the transmission factor. The projected controlled radioactive airborne particulate emissions releases for the FAA are shown in Table 3-1.

Table 3-1. Controlled Particle Radionuclide Emission Rates Projected for Fuel Assembly Area (Emissions at Stack).

Nuclide

$232 \mathrm{U}$

$234 \mathrm{U}$

$235 \mathrm{U}$

$236 \mathrm{U}$

$238 \mathrm{U}$

$236 \mathrm{Pu}$

$238 \mathrm{Pu}$

$239 \mathrm{Pu}$

$240 \mathrm{Pu}$

$241 \mathrm{PU}$

$242 \mathrm{Pu}$

$237 \mathrm{~Np}$
Emission rate $(\mathrm{Ci} / \mathrm{yr})$

$4.36 E-09$

$3.06 E-08$

$3.52 E-10$

$6.33 E-09$

$5.32 E-11$

$8.76 E-12$

$5.65 \mathrm{E}-08$

$2.79 \mathrm{E}-07$

$2.08 \mathrm{E}-07$

7.93 E-06

$8.64 \mathrm{E}-11$

1.79 E-08 


\subsection{OFFSITE DOSES}

The AIRDOSE-EPA ("Clean Air Act Code") computer code was used to calculate the dose from FAA to the maximally exposed offsite individual, and thus demonstrate compliance with 40 CFR 61, Subpart $H$.

Meteorological data input to the AIRDOSE-EPA code include mixing height, rainfall rate, average air temperature, vertical temperature gradient, wind direction frequency, wind speed, and atmospheric stability. This information was obtained from the data base compiled by the Hanford Meteorological Station (HMS). The HMS data on airspeed, direction, and temperature are collected at a $124.9-\mathrm{m}(410-\mathrm{ft})$ tower located on the Hanford Site between the 200 East and 200 West Areas and at a second tower at the 400 Area. Wind speed and direction are based on hourly data collected at the 400 Area meteorological tower $10-\mathrm{m}(32.8-\mathrm{ft})$ level during the years 1983 to 1987 . Atmospheric stability was estimated from the temperature gradient between the $9.1-\mathrm{m}$ $(30-\mathrm{ft})$ and $60.9-\mathrm{m}(200-\mathrm{ft})$ levels at the HMS for the same period using standard methods of the U.S. Nuclear Regulatory Commission (NRC). Air temperature and mixing height are also 5-yr averages of hourly data. Temperature is measured at the tower $60.9-\mathrm{m}(200-\mathrm{ft})$ level, and mixing height data are collected by onsite acoustic sounders.

Joint frequency data, as reported by the HMS, are modified for input into AIRDOSE-EPA by conversion to true average and reciprocal average wind speeds for each direction and stability class. The meteorological data are then used to calculate $X / Q$ values for each radionuclide, which are also a function of radiological half-life and dry deposition velocity. For purposes of this calculation, deposition velocities are assigned as follows: $1.0 \times 10^{-3} \mathrm{~m} / \mathrm{s}$ for all particulate materials, $1.0 \times 10^{-2} \mathrm{~m} / \mathrm{s}$ for iodine isotopes, and zero for all gases.

Source Terms: Projected annual releases from FAA as presented in Table 3-1.

Release Height: The FAA stack height is $109.7 \mathrm{~m}(359.9 \mathrm{ft})$

Inhalation Rate: $8,500 \mathrm{~m}^{3} / \mathrm{yr}\left(300,173 \mathrm{ft}^{3} / \mathrm{yr}\right)$.

Maximally Exposed Individual: Doses were estimated for an individual living $8.7(5.4 \mathrm{mi}) \mathrm{km}$ south of the 4862 Building.

Meteorology: The HMS data and onsite meteorological data, as discussed above.

Maximum individual doses were much less than $1 \mathrm{mR}$. Bone surface and lung were the organs receiving the highest dose, primarily from $238 \mathrm{Pu}$. Inhalation was the dominant pathway for exposures.

Table 3-2 shows the whole body and critical organ doses to the offsite individual receiving maximum exposure to airborne radiological emissions from the FAA. 
Table 3-2. Offsite Dose Estimates for an Individual Receiving Maximum Exposure to Airborne Radiological Emissions from Fuel Assembly Area (mR).

\section{Whole body} 4.8 E-06
Critical organ (bone surface)

National ambient air quality standards for U.S. Department of Energy (DOE) facilities, are stated in 40 CFR 61.92, as follows:

Emissions of radionuclides to air from DOE facilities shall not exceed those amounts that cause a dose equivalent of $25 \mathrm{mrem} / \mathrm{y}$ to the whole body or $75 \mathrm{mrem} / \mathrm{y}$ to the critical organ of any member of the public.

A comparison of the data presented in Table 3-2, above with the cited statutory limits for whole body dose shows that the projected airborne radionuclide emissions from FAA to the maximally exposed offsite individual would constitute only $1.0 \times 10^{-4}$ of those cited limits.

Further, the Hanford Site Environmental Report for Calendar Year 1988, (Jacquish 1989), a copy of which is available to the EPA upon publication, states that the effective dose equivalent (whole body dose) to the maximaliy exposed offsite individual from all Hanford Site operations air emissions was $0.3 \mathrm{mR}$ in 1988. If the projected whole body dose from the FAA as 1isted in Table 3-2 is added to the historic releases for 1988, it is clear that the FAA projected emissions will not cause a violation of either state or Federal standards. 


\section{REFERENCES}

Jacquish, R.E., 1989, Hanford Site Environmental Report for Calendar Year 1988, PNL-6825, Pacific Northwest Laboratories, Richland, Washington.

McDowell et al. 1976, Penetration of HEPA Filters by Alpha Recoil Aerosols, W. J. McDowe11, and F.G. Seeley (Oak Ridge National Laboratory), and

M. T. Ryan (University of Lowe11, Massachusetts), 14th ERDA Air Cleaning Conference, Sun Valley, Idaho, August 11-13, 1976. 
DOE /RL - 89-21

CORRESPONDENCE CONTROL

Number of Copies

ONSITE

9

Correspondence Control

J. D. Bauer

B3 - 15

D. G. Carter

R. J. Laudon

$\mathrm{N} 1-49$

$\mathrm{H} 4-50$

I. M. Metcalf

$\mathrm{K} 6-22$

R. C. Nickols

B3 -02

K. L. Young

$\mathrm{N} 1-40$

EDMC

$\mathrm{H} 4-51$

Publications Service

Central Files (3)

A2-24

L8-04

Distr. -1 